\title{
Review of Modelling and Simulating Crowds at Mass Gathering Events: Hajj as a Case Study
}

\author{
Almoaid Owaidah', Doina Olaru², Mohammed Bennamoun ${ }^{1}$, Fer-
dous Sohel $^{3,1}$, Nazim Khan $^{4}$ \\ ${ }^{1}$ Department of Computer Science and Software Engineering, The University of Western Australia, 35 Stirling \\ Highway, Crawley WA 6009, Australia \\ ${ }^{2}$ Business School, The University of Western Australia, 35 Stirling Highway, Crawley WA 6009, Australia \\ ${ }^{3}$ College of Science, Health, Engineering and Education, Murdoch University, 90 South Street, Murdoch 6150 \\ Australia \\ ${ }^{4}$ Department of Mathematics and Statistics, The University of Western Australia, 35 Stirling Highway, Craw- \\ ley WA 6009, Australia \\ Correspondence should be addressed to22034028@student.uwa.edu.au \\ Journal of Artificial Societies and Social Simulation 22(2) 9, 2019 \\ Doi: 10.18564/jasss.3997 Url: http://jasss.soc.surrey.ac.uk/22/2/9.html \\ Received: 30-06-2018 Accepted: 08-03-2019 Published: 31-03-2019
}

\begin{abstract}
The Hajj is an Islamic pilgrimage that involves four main holy sites in Makkah, Saudi Arabia. As the number of participants (pilgrims) attending these events has been increasing over the years, challenges have arisen: overcrowding at the sites resulting in congestion, pilgrims getting lost, stampedes, injuries and even deaths. Although Hajj management authorities have employed up-to-date facilities to manage the events (e.g., state-of-the-art infrastructure and communication technologies, CCTV monitoring, live crowd analysis, time scheduling, and large well-trained police forces and scouts), there is still overcrowding and "unexpected" problems that can occur at the events. These problems can be studied and mitigated by prior simulation, which allows for preparation and deployment of the most appropriate plans for crowd management at Hajj events. This paper presents a comprehensive survey of crowd modelling and simulation studies referring to Hajj.
\end{abstract}

Keywords: Hajj, Crowd Modelling, Crowd Simulation, Big/Special Events, Mass Gathering

\section{Introduction}

1.1 Mass gathering (MG) events, such as sport (Olympics games and FIFA world cups), musical concerts, religious events and political events (such as procession, rallies and social riots) frequently occur around the world throughout the year (Krausz \& Bauckhage 2011: Alshammari \& Mikler 2015; Mahmood et al. 2017). An MG event is defined by World Health Organization (WHO), as "any occasion, either organized or spontaneous, that attracts a sufficient number of people to strain the planning and response resources of the community, city or nation hosting the event" (Alshammari \& Mikler 2015, p. 574). MG events vary depending on the purpose and the length of the event, number of attendees, location, and whether they are planned or spontaneous. According to Memish et al. 2012, at least 1,000 people must attend the event for it to qualify as an MG. These events present many challenges, such as crowd management, security, and emergency preparedness (Krausz \& Bauckhage 2011).

1.2 This paper focuses on one of the largest MG events in the world, the Hajj, an annual pilgrimage to the city of Makkah, Saudi Arabia, which consists of a set of religious rituals that should be done within a certain time frame in specific locations (Hajj holy sites) Seliaman et al.|2001). The Hajj presents enormous challenges for emergency awareness, crowd management and control, and disaster responses to unforeseen natural or humanmade threats (Alaska et al.|2017). It is especially difficult for the managing Hajj authorities when all pilgrims complete their rituals at one location and move together, in a short time to the next location Sowmya \& Kumar 2014). Rahman et al. 2017) mention that currently pilgrim numbers exceed 4 million and are expected to increase by $10 \%$ every year; many pilgrims are elderly, illiterate and come from developing countries. One of the major issues surrounding this MG event is that Hajj must be completed over a limited and fixed schedule in five days. Hajj rituals are performed as a specific sequence of activities within a geographical area of $400 \mathrm{ha}$. 
The precision and strictness of the rituals result in disasters almost every year, arising from problems such as overcrowding, crowd incidents (lost, injured or dead), medical emergencies, guiding the lost and congestion management (Sowmya \& Kumar 2014). In order to face these challenges, Hajj authorities require accurate and real-time estimation of crowds at different locations, to allow intervention before any critical situation occurs Yaseen et al. 2013). Hajj management also involves monitoring and controlling pilgrims (based on analysis of their movements) and providing early warnings of any unusual behaviours such as a build up at a certain location Khozium et al. 2012). Although one of the Hajj crowd management goals is to preserve an adequate level of comfort during pilgrims' movements at Hajj holy sites, a commitment to crowd safety is a key element of crowd management to ensures that participants at Hajj are protected in both emergency situations and normal conditions Al-Nabulsi 2015. Crowd management also involves developing plans and actions from the examination of causes of previous crowd disasters, to prevent them from occurring again.

1.3 This paper summaries previous crowd modelling and simulation studies for Hajj events and their findings through a systematic literature review. Section 1]covers the introduction of the research and the motivation for choosing the Hajj event as a case study (the significance of Hajj as an MG event). Section 2 describes the framework followed in the literature search. Section 3 focuses on describing the event and the holy sites where Hajj is performed. In addition, the significance of Hajj as a mass gathering event, the complexity of Hajj crowd management, the overcrowding challenges and unexpected problems that might occur in future Hajj events are also included. Section 4 reviews the work undertaken on crowd modelling and simulation with special attention on the Hajj. This is followed by a discussion of these studies Section 5, and finally, conclusions are presented.

\section{Literature Search Framework}

2.1 A review of the literature was conducted in accordance with PRISMA guidelines to capture relevant studies modelling Hajj events. The following steps were included Cablová et al. 2017):

A. Aim of review

The main objective of the review is to analyse and summarise results of studies in crowd modelling and simulation for Hajj events under normal and emergency situations, and therefore identify the main crowd management strategies that could be applied.

B. Included research questions

- How could crowd modelling and simulation of mass gathering events be conducted under normal and emergency (evacuation) situations?

- How could crowd modelling and simulation of mass gathering events provide Hajj crowd management guidance and strategies at Hajj holy sites?

- How could crowd modelling and simulation of mass gathering events be improved by combining both micro and macro level modelling techniques?

C. Identifying data sources

Most of the search was undertaken using the databases of IEEE, Science Direct, Elsevier, ACM Digital Library, Springer Link, Research Gate, Oxford database, JASSS, arXiv and The University of Western Australia database (OneSearch). The search was conducted in October-December 2017. This review also used the Saudi Civil Defense website, which is a Saudi Arabian governmental portal for identifying the main future risks at the Hajj holy sites.

D. The process of selection criteria and data collection

The data collection strategy and the selection criteria in this review paper focus on two main topics: Hajj as a case study of MG event and models to simulate crowds at this MG event as a solution for managing these crowds. This review includes both academic and grey literature published in English between 2002 and 2018. Cross-searching was carried out using strings of search terms given in Table 1

E. PRISMA Flow diagram

Figure 5(from the Appendix) presents the criteria for inclusion and exclusion of the papers and the PRISMA Flow. Papers were screened and retained if they were: (a) peer-reviewed; (b) accessible in full text form; and (c) specifically presenting a modelling approach, not only presenting the Hajj events. Table 5 Appendix presents the final studies selected for this literature review, including their keywords and their compliance with the selection criteria. Duplications were removed, and abstracts and papers were eliminated if they were not eligible (e.g., medical studies focusing primarily on epidemiological aspects). 
F. PRISMA Check list: available in Table 6 Appendix.

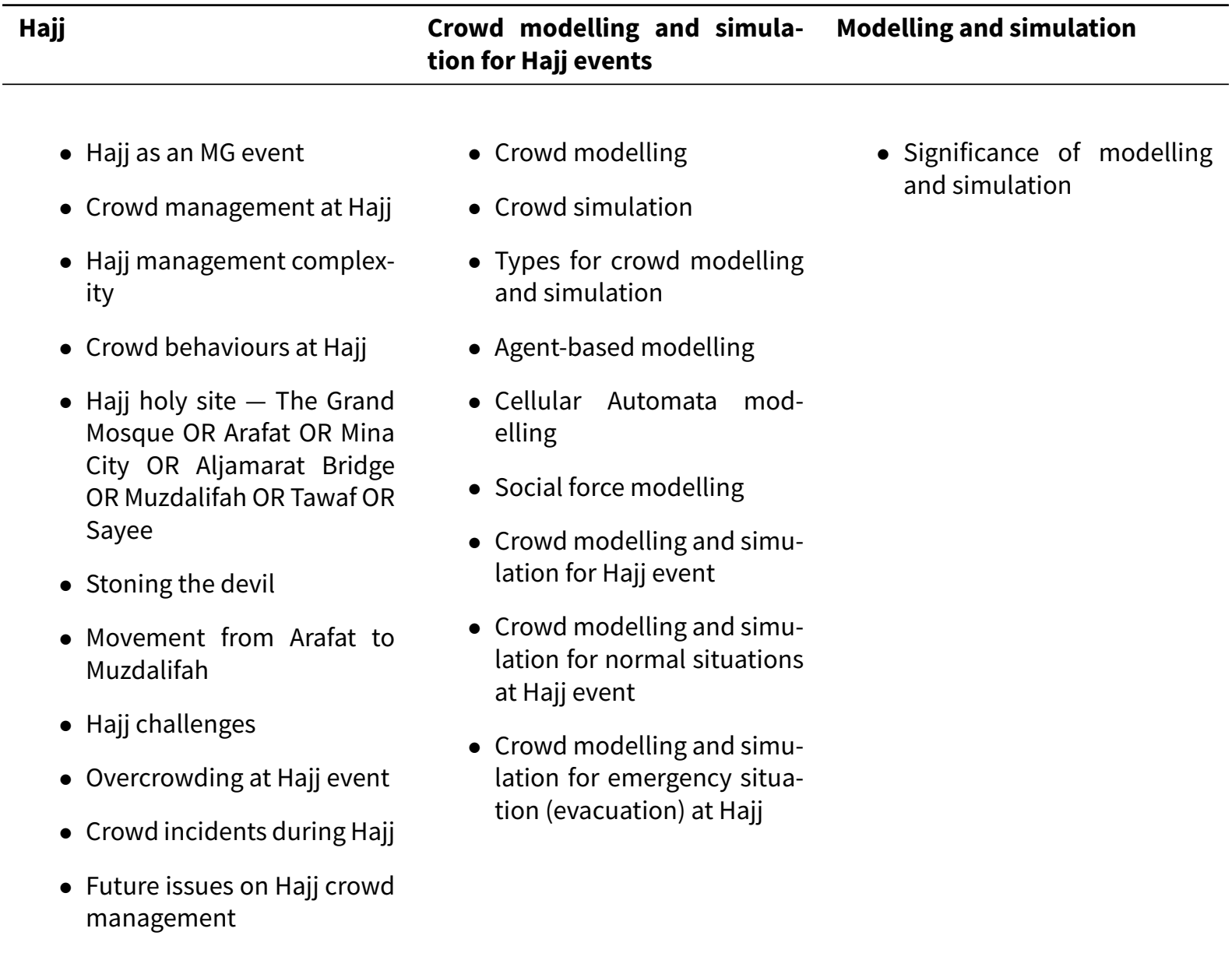

Table 1: Keywords for the analytic search of the literature. Note: Both US and UK/Australian spelling were considered in the search.

\section{Hajj as a Case Study}

3.1 Hajj is considered to be the biggest annual mass gathering event in the world (Al-Nabulsi 2015). This pilgrimage is a set of rituals conducted over five days starting from the ninth and ending on of the thirteenth day of the month of Dull Hijjah in the Muslim lunar calendar (Kurdi 2017). Hajj is one of the obligatory five pillars of Islam, and is a duty that the physically able, healthy, and financially able are required to perform once in a lifetime (Memish et al. 2014). A myriad of studies have been conducted on Hajj from different research viewpoints. For example, Kurdi (2017) highlighted that research on Hajj should focus on the safety and quality of pilgrims' experiences. There are several other research studies related to particular Hajj events, for example Tawaf and Sayee rituals, the Aljamarat Bridge ritual, pilgrims' movements between the Hajj ritual places (Arafat, Muzdalifah and Mina city), accommodations at these places, medical issues and Hajj security (Khan 2012). Developing Hajj research projects is critical for several reasons (Kurdi 2017), but many were developed in response to the many injuries and fatalities of pilgrims that have occurred over the last two decades due to uncontrolled crowd movement at the Tawaf and Aljamarat area. As the number of pilgrims has been increasing, existing facilities at Hajj sites get even more congested due to overcrowding.

3.2 Alaska et al. (2017) have outlined Hajj is considered as a unique MG event due to both its size, but also to the heterogeneity of the crowd. Each country that might be represented has limited attendance allocations (country quota) and as a result, the majority of pilgrims have to wait for a long time before they leave for Hajj. This process leads to a majority of older pilgrims performing Hajj rituals in extreme environmental conditions (the temperature often exceeds 37 degree Celsius) and moving in large groups at overcrowded locations. 


\section{Hajj holy sites}

3.3 The Hajj rituals are performed at The Grand Mosque (Al-Masjid Al-Haram) and holy sites. These sites include three separate areas (see Figure 11. These are Arafat (approximately $20 \mathrm{~km}$ from the Grand Mosque), Muzdalifah (approximately $13 \mathrm{~km}$ from the Grand Mosque) and Mina (approximately $6 \mathrm{~km}$ from the Grand Mosque). Pilgrims move between Hajj ritual sites by walking, or using dedicated public transport (buses or trains). More than 20,000 buses are used to transport pilgrims between these sites, while trains transport 72,000 pilgrims per hour (Al-Nabulsi 2015).

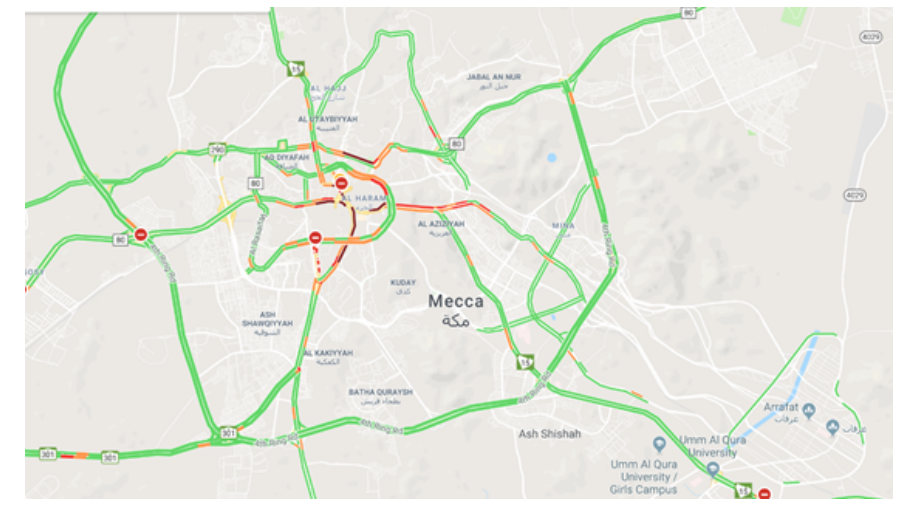

Figure 1: Hajj holy sites, Makkah City (authorsâĂŹ' figure using Google Maps).

\section{The Grand Mosque (Almasjid Al-Haram)}

3.4 The Grand Mosque (Al-Masjid Al-Haram) covers an area of 35.68 ha and includes outdoor and indoor prayer spaces (Rahman et al. 2017). The total capacity of these spaces is about 2 million. When Al-Masjid Al-Haram is completely occupied, it accommodates an average crowd density level of 4 people $/ \mathrm{m}^{2}$. However, there are specific locations, such as around the Ka'bah, where the crowd density reaches 6-8 people $/ \mathrm{m}^{2}$.

3.5 Al-Masjid Al-Haram has had a number of extensions as a response to the spatial needs of the increasing numbers of pilgrims (Tunasar 2013). Any further expansion has to deal with spatial, architectural, structural, historical, and managerial boundaries. Pedestrian counts and statistics indicate that the number of people inside and outside Al-Masjid Al-Haram (plazas) reaches 366,000 pilgrims at peak time (Shalaby et al. 2013). These people need to exit the space after an hour, as a similar number of people will enter for the next hour.

\section{Mina City}

3.6 The site of Mina consists of city tents and Aljamarat Bridge. In 1995, the Saudi government built 100,000 tents, to provide temporary accommodation for millions of pilgrims (Al-Nabulsi 2015).

\section{Arafat}

3.7 The holy site of Arafat is one of the important sites of Hajj. Edrees (2012b) described Arafat as a 1,269 ha area, of which almost half $(44 \%=558.36 \mathrm{ha})$ is built up with the remaining $(56 \%=710.64 \mathrm{ha})$ representing roads and pedestrian routes. Arafat becomes the most crowded site on the second day of Hajj, because all pilgrims have to arrive, spend half the day and leave after sunset. This poses overcrowding problems at the nine main roads of access to and from Arafat and at Arafat railway stations.

3.8 After sunset, all pilgrims leave Arafat for Muzdalifah, which is about 7-8 km to the west. Both of these sites are linked via nine roads for vehicles and two roads for pedestrians. It is estimated that peak pedestrian flow rate between Arafat and Muzdalifah is approximately 500,000 pilgrims per hour (Abdelghany et al.2012.

\section{Muzdalifah}

3.9 The site of Muzdalifah is an open area of about 1,000 ha, located halfway between Arafat and Mina of Research Excellence CORE). After spending the day at the Arafat, pilgrims move to spend their night at Muzdalifah for the 
"Al-Nafrah". This mass movement of more than 2 million pilgrims takes place on buses, trains or by foot. While they are at this holy site, pilgrims collect pebbles for the following days rituals (Seliaman et al.2001).

\section{Aljamarat Bridge}

3.10 Edrees 2012a) describes Aljamarat Bridge as the heart and the bottleneck of Mina city (Figure 2. It has two main pedestrian routes to enter the bridge. The bridge consists of three main pillars, where pilgrims perform the ritual of stoning the devil. These pillars are the most crowded places at the bridge. The peak times at the bridge are on Day 3 (10th of Dul-Hijjah) from dawn till noon, on Day 4 (11th) afternoon and evening and on Day 5 (12th) afternoon. Aljamarat Bridge is additionally considered as a gateway for pilgrims heading to Makkah city to perform Tawaf ritual at the Grand Mosque [Al-Nabulsi 2009].

3.11 After the stampede of 2006, the Kingdom of Saudi Arabia government reconstructed Aljamarat Bridge (as shown in Figure 2 to prevent crowding and recurrent accidents, completing the project in 2010. At peak times, the density of crowd currently reaches 300,000 pilgrims per hour (Alaska et al.|2017). Features of the new bridge are as follows (Imam \& Alamoudi 2014):

- $950 \mathrm{~m}$ long and $80 \mathrm{~m}$ wide (the previous width was $40 \mathrm{~m}$ );

- Multi-level (ground, first, second, third and fourth);

- 11 entries and 12 exits;

- 20 hectares surface;

- Integral cooling system (maximum temperature inside the bridge is capped at 29;

- Many distributed CCTV cameras that transmit live videos to the control room;

- Unidirectional, to prevent counter flows.

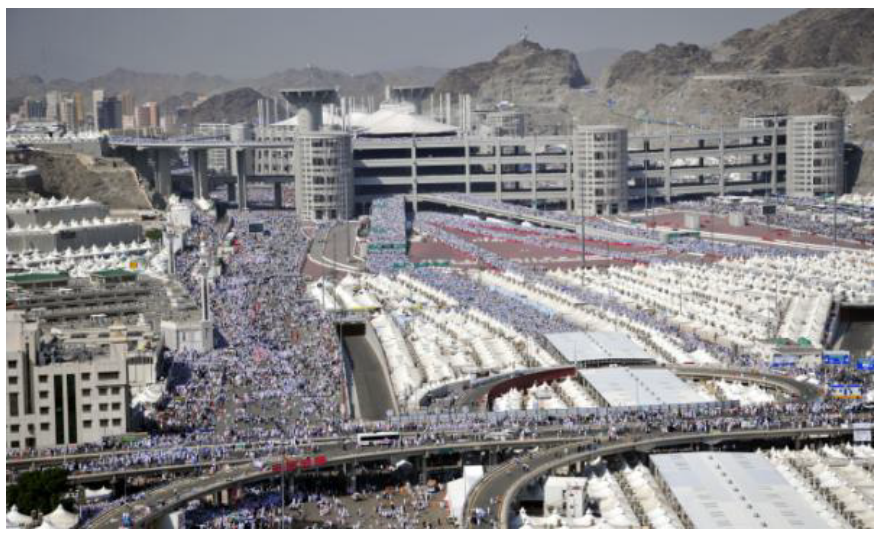

Figure 2: Aljamarat Bridge. Source: Edrees (2016).

\section{Hajj rituals}

3.12 Several papers have presented features of the individual Hajj events. For example, Zawbaa \& Aly (2012) briefly described the Hajj holy sites and their rituals over the five days ( $8^{\text {th }}$ to the $12^{\text {th }}$ of the Dull Hijjah). Here we summarise them (Table 2) and explain the main challenges at each site. 


\begin{tabular}{l} 
Hajj Ritual activity \\
\hline Tawaf on the $8^{\text {th }}$ of Dull Hijjah: The first ritual to perform when pil- \\
grims arrive to Makkah city for Hajj events. They circumambulate \\
the Ka'bah seven times anticlockwise.
\end{tabular}

Sayee on the $8^{\text {th }}$ of Dull Hijjah: This ritual requires walking back and forth between Safa and Marwah hills seven times

Staying in Mina on the $8^{\text {th }}, 10^{\text {th }}, 11^{\text {th }}, 12^{\text {th }}$, ( (ometimes on $\left.13^{\text {th }}\right)$ ): Pilgrims spend most of their days at Mina city

Standing on the Mount of Arafat on the $9^{\text {th }}$ of Dull Hijjah: The significant Hajj ritual, where all pilgrims must spend the second day at Arafat.

Staying at Muzdalifah on the $9^{\text {th }}$ of Dull Hijjah: After the ritual of Arafat, all pilgrims must leave and spend the night in Muzdalifah before the sunrise of the next day.

Stoning the devil on the $10^{\text {th }}, 11^{\text {th }}, 12^{\text {th }}$, (some cases on the $13^{\text {th }}$ ): Throwing stones at the pillars inside the Aljamarat Bridge, except stoning only the biggest pillar on the $10^{\text {th }}$ day.
Challenges

The Mataf (Tawaf area) is surrounded by a two-storey building, which accommodates $\mathbf{3 3 0 , 0 0 0}$ pilgrims, and creates overcrowding problem (Abdelghany et al. 2016).

The Sayee is a multi-storey area with two-way routes between Al-Safa and Al-Marwah mountains. This area is about $390 \mathrm{~m}$ long and $33 \mathrm{~m}$ wide. The crowd density in this area could reach $\mathbf{5 0 , 0 0 0}$ people with about 4-8 persons $/ \mathrm{m}^{2}$ which creates overcrowding problems Abdelghany et al. 2016.

Getting lost is expected at Tents City in Mina, as all these tents are white and look the same.

Many pilgrims spend most of their day time on top of this mountain. Therefore, this mountain is considered one of the most crowded places of Hajj event, creating conditions for many injuries and lost pilgrim cases.

Specifically, Edrees (2012b) noted the most crowded places at Arafat are: Alrahmah Mountain, Alnamirah Mosque, the pedestrian routes between the mountain and the mosque, the Arafat railway stations, and the exit gates from Arafat area.

It is estimated that peak pilgrim flow rate is $\mathbf{5 0 0 , 0 0 0}$ per hour from Arafat to Muzdalifah (Abdelghany et al.|2012). Therefore, crowd incidents (e.g. getting lost) are common during this movement.

Crowd incidents (e.g. getting lost) are expected in this area.

Table 2: Hajj rituals, their dates and challenges

\section{The significance of Hajj event}

3.13 The study of Owaidah (2015) described Hajj as a unique event for several reasons. First, Hajj represents one of the largest annual events globally, which attracts millions of pilgrims from more than 184 countries Rahman et al. 2017) within specific areas and for a limited period of time. This exceeds the scale of the mass gathering events for sports events, festivals, or concerts (Krausz \& Bauckhage 2011: Turris et al. 2014). Movements between the locations of Hajj ritual places (Arafat, Mina and Muzdalifah) adds to this unique profile. This is in contrast with most of the MG events (sporting or concerts) which, except for access and egress to the venue, are static Krausz \& Bauckhage 2011.

3.14 Second, the Hajj has witnessed many serious crowd incidents. Between 1994 and 2006, there were five major incidents, which led to 1,053 deaths and 1,295 injuries. Also, the Hajj brings together people from diverse cultures, language and countries (e.g. Indonesia, Pakistan, India, Turkey, Iran, Nigeria, Bangladesh, Egypt, European countries, USA, Russia and China). This impacts crowd management for pilgrims, as well as their response 
to any potential dangerous hazards. In addition, this cultural diversity dictates how the pilgrims perform the practices, depending on the individual's Islamic doctrine, and this potentially complicates the management of pilgrim movements between the holy places.

3.15 A useful classification of the features of MG events was provided by Turris et al. (2014) and presented in Table 7, Appendix As already highlighted, the multi-site, dynamic nature of the Hajj, combined with its sheer size and socio-demographics, make Hajj an exceptionally intricate case that requires special investigation and specific solutions. Felemban \& Basalamah (2011) describe additional characteristics, beyond wide national, social, cultural and educational diversity of participants that make Hajj so distinctive. Foreign pilgrims are 45 years of age or older, and as Hajj is performed once in a lifetime, this can create unexpected emotions and behaviours.

\section{Complexity of crowd management for MG events}

3.16 Because of their increasing popularity and higher rates/frequencies, safety measures for MG events are central issues on the agenda of MG organizers, to eliminate the likelihood of crowd disasters. Incidents may occur when the crowd densities become extremely high (Krausz \& Bauckhage 2011), reaching up to 10 people $/ \mathrm{m}^{2}$ and the solution is to keep flows separated (both in space and time) (Johansson et al. 2012). At high densities, 'stopand-go' waves or crowd 'turbulences' may occur and eventually could cause stampedes (Krausz \& Bauckhage 2011: Johansson et al. 2012.

3.17 In the past decade, the use of scheduling, crowd control, luggage management, video monitoring, and changes in the transport system for the event, have been implemented as solutions for crowd management at various events. In addition, work towards the prevention of crowd disasters included simulations of human behaviour in crowds. Using such simulations, one can identify and defuse situations potentially dangerous in any environment where crowds are present Johansson et al.2012.

\section{Crowd Management at Hajj}

3.18 Khan (2012) identifies Hajj management as the set of decisions to plan, organise and control every activity associated with Hajj events and with the rituals. These decisions are expected to lead to superior crowd performance considering safety, satisfaction and health conditions.

3.19 Al-Nabulsi 2015 emphasised that the preparation of Hajj crowd management is a complex task, taking about 12 months to organize for the next Hajj. During this period, extensive planning is prepared by the Hajj governmental agencies for supporting all Hajj sectors to carry out these plans during Hajj and to address major problems that could occur. Managing large crowds, whether pilgrims are performing rituals or moving between Hajj sites, is a daunting task for Hajj organizers Osman \& Shaout|2014 Reda 2016. As Hajj rituals combine two types of crowd dynamics, low-density unmotivated movements and high-density movements (Yaseen et al. [2013), it is essential to understand these processes through the analysis of pedestrian movements in massed locations, depending on varying circumstances (Aljohani 2015). In addition, analysis on overcrowding is critical for preventing people from being trampled or crushed.

\section{Overcrowding at Hajj holy sites}

3.20 Given the obligatory performance of specific rituals at specific times at specific locations (Reda 2016), large numbers of pilgrims move and gather while performing Hajj rituals, potentially causing bottlenecks. Potential resulting overcrowding can lead to stampedes, traffic and human jams, counter flows, stop-and-go waves, crowd turbulence, and panic (Friberg \& Hjelm 2015). All these consequences appear to be unavoidable despite many interventions with positive effects (expansions, careful planning of Hajj events). Thousands of people who have participated in crowded religious events have faced these problems while performing their activities Yamin 2015. A brief description of each of these potential effects follows.

3.21 Stampede is a collective rush of individuals in either unified or random directions Friberg \& Hjelm 2015. Human stampedes are the most common hazard to be seen at mass gathering events. They are characterised by massive flow of individuals in a crowd in response to a perceived danger. Stampedes could result in death due to trampling or suffocation under the high pressure caused by the push in the crowd Owaidah 2015.

3.22 'Stop-and-go waves' occur when the density of pilgrims is high, and the speed of pilgrims' movement is slow Friberg \& Hjelm 2015). The flow of pilgrims could last more than 20 minutes, and pilgrims start to move in 
all directions which can result in pushing and falling Owaidah 2015. However, when the density of the pilgrim movement becomes larger than stop-and-go waves (crowd density and speed are both high), crowd turbulence is produced (Friberg \& Hjelm 2015). A bottleneck is created when the natural flow of the crowd cannot continue due to obstacles (Friberg \& Hjelm 2015). The flow of bottlenecks differ depending on the width and length of the flow; longer and narrower flows are slower (Friberg \& Hjelm 2015).

3.23 Panic "... refer to situations in which individuals have limited information and vision (due to high crowd density and short time of egress), and which result in physical competition and pushing behaviour" Shiwakoti \& Sarvi 2013, p. 12, Owaidah 2015 p. 20). In addition, it could be defined as the breakdown of order when individuals may start anxious reactions in response to a certain event Helbing \& Johansson 2011; Owaidah 2015. In panic situations, many people attempt to escape from the threat, struggling for survival, which could end up crushing individuals in a crowd. Panic effects displayed in crowded locations could include: individuals move faster than normal; there are physical interactions between individuals (e.g. people start to push each other) or disorganized movements; there is build-up of panicked individuals and alternative routes or exits are unnoticed or are used inefficiently Office 2009, Owaidah 2015). Therefore, overcrowding and bad management at crowded areas lead to panic followed by injuries and crowd disasters (Halabi 2006, p. 28, Owaidah 2015). However, panic could be preventable using effective crowd management as a part of emergency planning (Drury et al. 2013, Owaidah 2015).

3.24 There are additional issues which increase the overcrowding problems at Tawaf area inside the Grand Mosque Shuaibu et al.2015): a) pilgrims who finished their Tawaf ritual are always close to Ka'aba. After they complete their ritual, they proceed in a pattern that forces them to collide with other pilgrims; b) congestion and blockage are due to the queuing at the Ka'ba gate and the 'Black Stone'; c) the entrance to the Tawaf area is not restricted to certain gates and pilgrims easily flow into the area through different directions, although physical constraints are the main challenges. Finally, traffic and human congestion can result in blocking the Hajj main roads for hours. Providing extra lanes to existing road infrastructure can ease congestion problems (Yamin 2015).

3.25 In conclusion, overcrowding and panic at religious sites can be contained, and crowd incidents could be prevented by efficient crowd management including sufficient prior planning, infrastructure improvements, deployment of more security officers and information technology improvements $\mathrm{H} \& \mathrm{~S}$. 2015). Moreover, understanding the role of the pilgrims themselves, such as their movements and behaviours, should be included in the crowd management process for training and education (H\&S.|2015).

\section{Previous Hajj crowd incidents and their main causes}

3.26 Numerous crowd incidents have occurred in the past two decades at Hajj events. These incidents varied by location (at Haram area and Hajj ritual sites, specifically Mina city) and causes, and are presented below.

\section{Incidents at the Grand Mosque}

3.27 Evidence from Table 8 Appendix shows that many of these crowd incidents were caused by human fault, with a range of different consequences. A tragic crane incident in 2015 led to 107 deaths and 200 injuries. However, minor incidents at Haram, such as getting lost (in large numbers in 2006, 2011 and 2013), occur recurrently. Due to the crowdedness of Haram area, incidents may occur in the future, which could lead to stampedes, congestion and exhaustion (Edrees 2016).

\section{Incidents at Aljamarat Bridge, Mina}

3.28 Table 9 Appendix shows most of the crowd incidents were at Aljamarat Bridge, Mina City, during the ritual of 'stoning the devil'. Edrees 2012a) identified the Aljamarat Bridge as the bottleneck of Mina. In the past, the Bridge had two main pedestrian routes for entry, from Muzdalifah and Almuasim. A stampede at the bridge in 2006 led to 1,035 deaths and 721 injuries (Helbing et al. 2007). The Office (2009) described the reasons for the 2006 disaster as overcrowding, enormous crowd pressures, lack of crowd management at the bridge and pushing forwards too quickly to perform the stoning ritual. Some pilgrims also insist on performing the stoning ritual on the right of the pillars, which could cause crowding around these pillars. The new infrastructure has alleviated this risk, and these incidents decreased radically since.

3.29 A stampede caused crowd incidents at Tents City in 2015. This incident was at the crossing of streets 204 and 223 Khan \& Noji 2016. These numbers show the 'unpredictability' of crowd incidents in Hajj, their impact, and that it is critical to prepare for these unexpected events (Aljohani2015. All of these could be achieved by simulation. 


\section{Incidents at Arafat and Muzdalifah}

3.30 Table 10 Appendix shows no casualties at Arafat or Muzdalifah. However, cases of lost people have occurred at these places. For example, in 2011, a total of 30,000 pilgrims were lost at Haram and Hajj holy sites (Amro \& Nijem 2012. Edrees 2012b explained some reasons for incidents in these areas: pilgrims insisting on approaching, climbing and standing on Alrahmah Mountain; pilgrims insisting on praying at Alnamirah Mosque at Arafat; exits from Alnamirah mosque and Arafat streets being joined which caused aggregation of pilgrims; pilgrims laying down on Arafat streets and paths; some pilgrims waiting at exit paths early to leave Arafat and head to Muzdalifah; traffic jams occurring at Muzdalifah after pilgrims leave Arafat; and lack of guidance and information distributed to pilgrims.

\section{Observations on past incidents}

3.31 The Defence (2017) has drawn attention to a number of past incidents and indicated future issues which may present at Hajj holy sites. Past observations include: construction incidents; walking/crossing traffic (not using pedestrian pathways); walking through emergency pathways; resting at the pedestrian pathways; lack of awareness about Hajj sites emergency exits (evacuation precautions); problematic crowd behaviours inside pedestrian tunnels; and falling rocks while climbing Al-Rahmah Mountain (Arafat).

3.32 Jbira \& Lakhoua 2012 offered insight into why future stampedes, congestion and crowd panic at Aljamarat Bridge might occur. For example, new pilgrims may find it difficult to recognise the ground floor entrance due to the crowds. There is also a general lack of understanding of instructions provided, and there are not enough tools or methods to alert event organisers to the problem before complications occur. Therefore, crowd modelling by simulating crowd scenarios under different situations could help in planning better crowd management and control strategies (Sharma et al.2018).

\section{Literature Survey Results}

\section{Crowd modelling and simulation types}

4.1 Bakar et al. 2017, p. 1) identified modelling as “... a method of solving problems, in which the approach under investigation is controlled by a basic pro-test that illustrates the genuine framework and/or its operation". They identified simulation as "... a decision support tool to predict the system behaviour by answering the "what-if scenarios"'. In addition, crowd simulation is the process of replicating the movement of large numbers of entities, characters, agents or pedestrians. It represents the motion and behaviours of the crowd either via twodimensional (2D) or three-dimensional (3D) computer graphics (Nasir \& Sunar 2016).

4.2 Crowd simulation models can be used to predict crowd behaviours and movements and performance issues related to infrastructure (buildings and public facilities) designs (Sarmady et al. 2010). These models could also be used to estimate evacuation time in emergency situations.

4.3 Many modelling and simulation methods for pedestrian crowds have been proposed. They can be categorised into two broad categories: (a) Microscopic models, dealing with individual pedestrians, or (b) Macroscopic models, dealing with aggregate characteristics of the crowds (Rahman et al. 2017). They are presented in the following subsections.

\section{Agent-Based Models (ABM)}

4.4 ABMs are microscopic models focusing on the interaction among heterogeneous agents, each with their own set of characteristics/endowments and following their rules of interaction, according to their objectives Bonabeau 2002). Given that agents are autonomous, responsive, proactive and social, the macro-level outcomes cannot be directly predicted, but they rather emerge from the interactions. 


\section{Social Force Models (SFM)}

4.5 SFMs are widely used to model human pedestrians (Bakar et al. 2017). These models are suitable to imitate human behaviours and can generate collective behaviour of pedestrian flow, as individuals follow others. These models can produce smooth movements, accurate and realistic results (Sarmady et al. 2010.

\section{Cellular Automata (CA) models}

4.6 CA uses 'cells' occupied by agents (Bakar et al. 2017). These models examine the movement of agents from one cell to another empty cell. Sarmady et al. (2010) describe CA models as using simple and flexible transition rules to identify the cell to which an agent will move next. CA models for crowd applications divide the movement space into big grid cells, each cell accommodating an agent. During simulation, agents stay in the current cell or move into one of the neighbouring cells. One of the limitations of the CA setup is the similar speed of the agents in the cells and the identical size of the cells. In real life, pedestrians have different movement speeds and the space they occupy during rituals also differs.

4.7 Regarding crowd modelling and simulation for Hajj events, Hajj crowd management and evacuation procedures during both normal and emergency situations justify significant attention, given their recurrent nature Mohamad et al.2014). Modelling and simulation are therefore important, as they are tools that can be used to assess safety and take appropriate precautions. Reda 2016 concluded that in order to manage crowd movements efficiently at Hajj events, crowd behaviours, dynamics, formation causes, and formation patterns should be better understood. Crowd modelling and simulation offer opportunities for studying and analysing crowd behaviours and crowd dynamics, in order to predict crowd movements. In addition, Alaska et al. (2017) mentioned that using crowd simulation models helps to assess the best methods of grouping and scheduling pilgrims, managing and controlling crowds and luggage management, as well as informing pilgrims of changes in the transport system used during the event.

\section{Significance of crowd modelling and simulation}

4.8 Computer modelling and simulation can be used to inform and optimise decision-making for implementing change in real-life scenarios (Tayan 2010). In regard to crowd events, computational techniques are needed for observing behaviour in dense crowds, such as trampling, falling, collision, or pushing Kurdi et al. 2015. This is particularly relevant for optimising the movements and flow of pilgrims between the holy ritual places at the Hajj events. Simulation models are 'dynamic' and allow unpredictable behaviours to appear: "Goal of the simulation is to reproduce realistic scenarios of such situations evolving in real-time involving a large number of virtual human agents" Ulicny \& Thalmann 2001, p. 163, Office 2009, p. 193). Crowd simulation of different scenarios could help in achieving better crowd management and control strategies (Sharma et al. 2018.

4.9 Kabalan (2016) highlighted several reasons for using crowd dynamics simulation: help to devise measures aimed at increasing the level of comfort of pedestrians; suggest detail planning for pedestrian paths; and manage crowds to ensure a safe environment for a large number of pilgrims. Crowd evacuation in emergencies (in a short time and under stress conditions) could be improved. In addition, simulation could help to understand the principles and mechanisms of collective motion and self-organisation phenomena such as shock waves, oscillation at bottlenecks and lane formation.

\section{Previous Hajj simulation studies}

4.10 Computer simulation is a fitting tool to investigate crowd movements and evacuation processes (Kabalan2016). Due to several overcrowding incidents at Hajj, efforts have been made to address these processes by using crowd simulation models (Johansson et al.2012). Sharma et al. 2018) showed that data collection (such as video records and traffic counts) enables validation of crowd simulation of Hajj events, offering suggestions for changes in event management and control, and event execution and infrastructure. This literature review focuses on two groups of Hajj studies that simulate rituals at two main locations; Tawaf in the Grand Mosque, and Jamarat at Aljamarat Bridge. 


\section{Simulating crowds during Tawaf and Sayee rituals}

4.11 Crowd simulation for Tawaf and Sayee rituals uses complex flows of motions, variable velocities, high density and heterogeneous (varieties) populations (Kurdi et al. 2015). In addition, there are significant factors that most of the previous studies focused on, such as the Tawaf (circumambulating the KaâÁźbah) area, pilgrim behaviours and the crowd size Kurdi et al.2015. Regardless of the modelling approach, many earlier studies had a common limitation which can now be overcome: the inability to capture the scale of real events. Most models used ABM, SFM and CA approaches.

4.12 Mulyana \& Gunawan 2010 simulated pilgrims performing Tawaf as 'intelligent' agents, able to recognise the environment and to undertake various actions. Agents' behaviours were depicted to reflect pilgrims' behaviours in real situations. Each agent needs to know the individual current location to determine appropriate behaviour and do specific activities according to the environment. For example, during Tawaf ritual, each agent circles the Ka'bah in an anticlockwise direction, to avoid collisions at crowded places in the Tawaf area, such as gathering around the Black Stone (Al-Hajar Al-Aswad), Maqam Ibrahim and Hijr Ismail. The objective of Mulyana and Gunawan's 2010) work was to develop Hajj crowd simulation based on agents able to recognise the environment and perform natural and complex behaviours. The results of this type of simulation were superior, demonstrating more realistic behaviour for Tawaf ritual Kurdi 2017). This simulation can be used for training pilgrims before they perform the ritual. However, the limitation of this study is that the number of agents to be simulated was low; also, some optimisation in this model can be applied, such as using better collision detection in the crowded places.

4.13 Khan \& McLeod 2012) developed an ABM to investigate the effect of Al-Masjid Al-Haram courtyard layout on pilgrims' movements during Tawaf, to analyse pilgrims' crowd properties (features) and provide a tool for the Hajj authorities to manage crowds, maximise the safety of pilgrims (lack of collisions) and protect their health (against spread of disease). They developed the TawafSIM micro-level simulator, which models pilgrims performing the Tawaf ritual, to explore the impact of crowd characteristics and management preferences on Tawaf performance with respect to pilgrims' satisfaction, health and safety. The authors simulated 42 scenarios in 12 different categories, using colours to indicate the congestion at the Mataf area (Figure 3 , colours denote their spiralling status). Red dots indicate that pilgrims are spiralling inward from the edge of the crowd boundary to the external half of the circles. Green dots represent maintaining the radius at circles near the Ka'bah whereas blue dots are for pilgrims who are spiralling outwards. Black dots are for pilgrims who have completed the seven rounds and are spiralling outwards to exit from the crowds. The 5th category, yellow, which is dispersed throughout the crowd, represents agents who change their route in order to avoid crowd collisions.

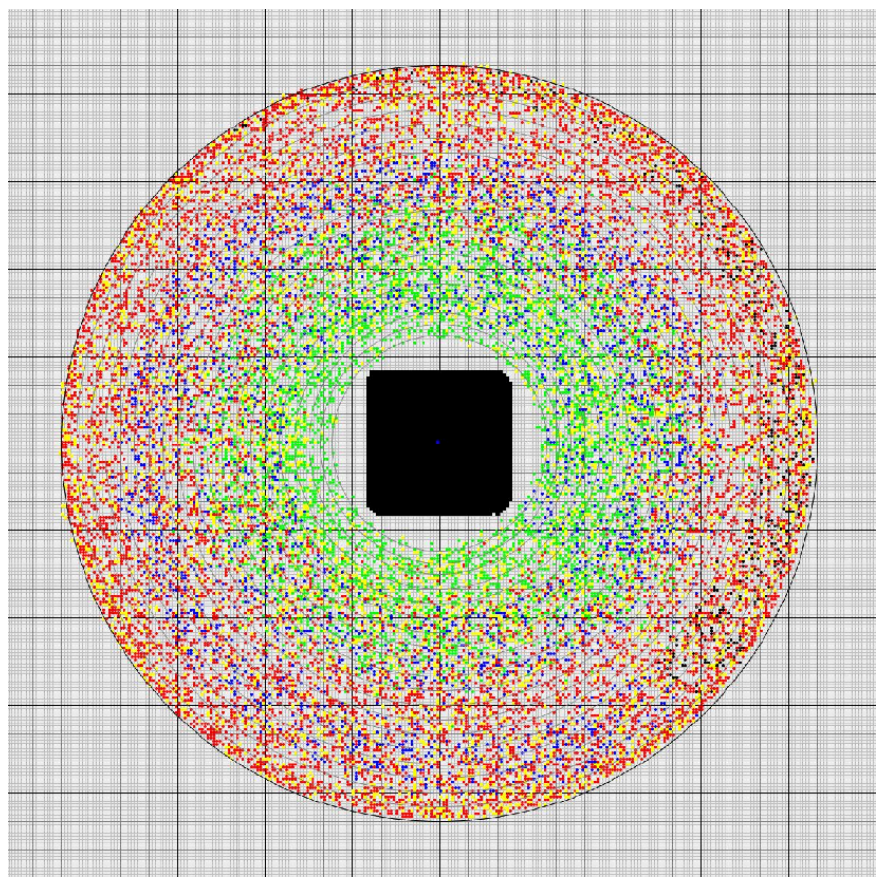

Figure 3: Snapshot of TawafSim simulator. Source: Khan \& McLeod 2012.

4.14 Khan \& McLeod 2012 combined ABM with Finite State Machine (FSM), which uses a geometric collision avoid- 
ance algorithm. The FSM algorithm was used to model each pilgrim (agent) and to control agentâĂŹs activities when interacting with other agents. Kurdi (2017) mentioned that although this study provides many recommendations regarding crowd management, crowd behaviour and facility layout for safety and throughput, it could be enhanced by using an appropriate crowd simulator with the ability to simulate large numbers of pilgrims and to develop behaviour metrics. This study could be also applied for the crowd management of Tawaf ritual on the other two levels, and the Sayee area of Al-Masjid Al-Haram.

4.15 Kim et al. 2015) modelled the physical interactions between agents by using an interactive velocity-based multi-agent framework relying on the agents' ability to anticipate and avoid collisions. This framework was able to model complex behaviour relating to social and cultural rules. The authors used FSM to define a series of behaviours and parameters for their physical interaction model. The work simulated 35,000 agents in dense scenarios $\left(8\right.$ agents $/ \mathrm{m}^{2}$ ). As a result, this work was able to simulate complex interaction between agents and dynamic obstacles in the environment, generating many emergent behaviours. Che et al. (2015) mentioned that this study combined velocity-based and avoidance algorithms with FDM to model both physical forces and interactions between the agents and obstacles. Additionally, it allowed agents to anticipate and avoid collisions during local navigations: e.g. pilgrims performing Tawaf at Mataf area while avoiding each other and avoiding colliding with Hijr Ismail or Maqam Ibrahim. However, they modelled a small number of agents, compared to the number of pilgrims during Hajj.

4.16 Sarmady et al. 2008 proposed a CA model to simulate pilgrims performing Tawaf rituals. They pointed out that most of the previous systems were unable to simulate pilgrims' movements in Tawaf area with enough agents. Therefore, their proposed model was developed to simulate large crowds of pilgrims and combined a macroscopic model for the crowd movement with CA to simulate collision avoidance and to identify the shortest paths. Their integrated system was capable of simulating between 20,000 to 23,000 agents in real time. In addition, they compared the velocity of the crowds obtained from empirical observations and simulation snapshots with photos taken from the Tawaf area to validate their model. This study was mainly focused on simulating a large number of pilgrims moving at the Mata area (Mohamad et al. 2014) however, their system failed to consider behaviour such as pushing, falling and grouping (Mohamad et al. 2014).

4.17 Siddiqui \& Gwynne 2012 used a crowd simulation model known as EXODUS to simulate pilgrims performing the Sayee ritual at the Grand Mosque (Almasjid Alharam). Their model was used to understand individual behaviour when simulating large crowds in emergency situations. This study focused on analysing both pedestrian and evacuee behaviour and used observations by the lead author during his own pilgrimage in 2008 (notes, video footages and still photographs) to calibrate the model. These observations recorded the pilgrims' actions along with the surrounding influential factors and the resulting emergent conditions. The authors decided to use EXODUS due to its ability to produce a range of outputs that allow performance to be examined at the individual, group or population level. Three scenarios were examined: Scenario 1 used the model's default movement parameters with travel speed ranges between 1.2 âĂş $1.5 \mathrm{~m} / \mathrm{s}$; Scenario 2 used modified movement parameters to reflect the observed travel speed around $1.0 \mathrm{~m} / \mathrm{s}$; and Scenario 3 was similar to scenario 2, but included a subset of the procedural activities, to reflect the individual actions. Two sets of simulations were conducted for each scenario. In the first set (Case A), an individual pilgrim was simulated performing Sayee 3.5 times. In the second set (Case B), a representative population of 15,000 pilgrims was simulated. The individual routes were affected by the introduction of individual task itineraries and producing more complex and vibrated behaviours (Case A), while in Case B, the more complex routes were combined to produce emergent behaviours similar to those observed in the real events. Therefore, this model showed the relationship between pilgrims (agents) and the levels of congested areas from different observations from the Tawaf ritual (Shuaibu et al. 2015). This model was used for prior planning of crowded events, examining all possible and anticipated scenarios for managing crowds in normal and dangerous situations. This process could also be conducted for any crowded places outside Al-Masjid Al-Haram.

4.18 Zainuddin et al. (2009) simulated the circumambulation of Ka'bah using the crowd simulation model SimWalk. The authors underlined two main problems in the Tawaf area. First was the large number of pilgrims in this area, which causes pilgrims to push each other. Second, the area has unlimited bi-directional entries, which result in pilgrims entering and exiting at the same time and causing congestion. Therefore, this study suggested various mitigation measures to ease the pilgrim flows in the Tawaf area: building a spiral path, encircling the Ka'ba venue seven times, but with the path entrance at the outermost fold, and the completion of the Tawaf at the innermost fold, leading to an underground tunnel; and waiting points around the Ka'ba, which can direct pilgrims to walk around the Ka'ba without building congestion. The results of this study showed that building the spiral path is an effective solution in ensuring smooth crowd flows in the Tawaf area. However, the authors mentioned that this approach might not be realistic to implement, as the underground tunnel involves additional costs and may be infeasible (historical items located below the Tawaf area). As a result, an alterna- 
tive approach was building an overhead bridge that links the centre of the Tawaf area to the exit of the Grand Mosque. The main drawback of this study is simulating only 1,000 pilgrims, which is insignificant compared to the real number of pilgrims $(300,000)$ in Tawaf ritual during Hajj.

4.19 Dridi 2014 used PedFlow to simulate pilgrims performing rituals in the Tawaf and Sayee areas. The model was verified and validated using data collected during Hajj 2009 and included walking time and the number of pilgrims and crowd density at the Grand Mosque gates before and after each prayer. The following methods were applied: 1) Comparisons of PedFlow results with video recordings of Hajj 2009; 2) Comparisons between PedFlow results and other simulation models results, such as Simulex/Myriad. The Pedflow results were more sophisticated in predicting the high density of crowd and crowd dynamics; 3) Sensitivity analysis showing the effect of different input values on the simulation outputs. Dridi 2014 concluded that PedFlow can produce realistic crowd motion with agents moving at different speeds and under different situations using avoidance action (collisions). However, this model should be tested again with new updated data of crowds at Mataf area and Sayee area at Al-Masjid Al-Haram or other locations.

4.20 Nasir \& Sunar 2016 presented a study to simulate group behaviour while performing Tawaf under normal circumstances. Their study implemented SFM, modified to simulate group dynamics, by integrating the flocking technique into the SFM. Flocking is a popular technique to simulate large groups of agents. Reynolds (1987), the proponent of this technique, was inspired by the behaviour seen in flock of birds and schools of fish. He introduced an approach of simulating groups behaviours based on the interaction between agents following simple rules, called 'BOIDS'. In the Tawaf simulation, this integrated model was used to simulate group behaviours while in the circular motion. Several behaviours were observed through the simulation. For example, the group members maintained their position to be as close as possible to each other. In addition, if one of the group members was left slightly behind, the whole group would reduce its speed accordingly, and the separated pilgrim increase his/her speed to catch up with the group. This study is useful to understand pilgrims' behaviours in a crowd in both normal and emergency situations and to aid Hajj authorities to plan for optimal crowd flow and prevent crowd incidents. However, the applicability of this model to large scale crowd is yet to be determined, as the number of the simulated agents was only 500.

4.21 Mahmood et al. 2017) proposed an ABM crowd simulation and analysis framework. They developed the model in a software platform called "Anylogic" and integrated it with external modules for optimisation and analysis of the crowd simulation results. Anylogic crowd simulation model provides both user-friendly integrated environment and an efficient simulation engine. These tools allow modellers to quickly create and simulate dense crowds. The main features of the proposed framework were: the ability to model a large crowd in a spatial environment at real-scale (e.g. stadium, malls, large mosques and spatial networks); simulating movement of high density crowds and their complex behaviours such as emergency evacuation using different experimental settings; and detailed assessment of crowd management and control strategies to evaluate evacuation plans.

4.22 This framework was used to evaluate three emergency evacuation strategies during Hajj: Random Crowd Evacuation (the crowd selects its exit randomly); Shortest Regional Distance (the crowd select the nearest gate by using the shortest path for evacuation); Genetic Algorithm (the crowd select the best evacuation solution that will minimise the total evacuation time for the whole crowd).

4.23 Using the proposed model for simulating crowd evacuation from the Grand Mosque led to the following results were obtained from 10 runs/strategy (Table 3 .

\begin{tabular}{ll}
\hline Simulation factors & All three evacuation strategies \\
Population & 10,000 agents \\
Evacuation time & 1.3 minute \\
Average speed of the crowd & Min $=1.0 \mathrm{~m} / \mathrm{s} ;$ Max $=2.0 \mathrm{~m} / \mathrm{s}$ \\
& Most likely $=1.4 \mathrm{~m} / \mathrm{s}$ \\
\hline
\end{tabular}

Table 3: Anylogic results. Source: Mahmood et al. (2017)

4.24 More needs to be done to observe the crowd density at peak times of all Hajj days, in all sections of Al-Masjid Al-Haram and compare to the capacity. This process will help Hajj organisers to identify the crowded zones at observed locations, to direct and distribute pilgrims to uncrowded spaces to perform their Tawaf ritual and thus decrease congestion at the main Mataf area.

4.25 The results were similar for the three different crowd evacuation strategies. The authors stated that when the crowd simulation would include more complex physical behaviour, the performance of those evacuation strategies may differ. They also suggested that the proposed framework can be easily implemented as public safety 
and security management for events, being beneficial for developing and supporting decisions. However, several drawbacks limit its application: no crowd management strategies are devised for normal situations; and the number of tested agents in the simulation is small compared to the real number of pilgrims located inside and outside the Grand Mosque at Hajj peak time (over 300,000 pilgrims).

\section{Simulating crowds at Aljamarat Bridge ('Stoning the Devil' ritual)}

4.26 Based on a video analysis of unique recordings of the human stampede of 2006, Helbing et al. 2007) presented explanations for the causes of the tragical incident, as well as solutions for improving the crowd management. According to their analysis, two sudden transitions led to "stop-and-go" flows at the entrance of the old Aljamarat Bridge and then "turbulent flows" and pressures occurred when the crowd density reached 9 pilgrims $/ \mathrm{m}^{2}$. The resulting stampede led for the loss of 346 lives and many injured pilgrims. Helbing et al. 2007) recommended several improvements:

- Increasing the stoning capacity and the crowd capacity at different levels of the bridge, by extending the three pillars using elliptical shape, as previously suggested by Dr Keith Still;

- Preventing crowd accumulation in the plaza around the Aljamarat Bridge and further designing a new plaza that allows the General Security to easily balance the pilgrims flows between the ground floor and the Northern and Southern ramps of the first floor; this would preclude overcrowding and breakdown of pilgrim flows;

- Replacing the two-way pilgrim flows on the streets and on the bridge by a one-way traffic, to avoid obstructions and counter-flows;

- Using a systematic scheduling system to homogeneously distribute pilgrims at the bridge;

- Providing an automated counting system of pilgrims and constant monitoring using the CCTV cameras.

4.27 Some of these recommendations were later appreciated to have had a key role in improving the organisation of the ritual after 2006: e.g., the separation of the flow's directions and the reservation of space for emergency operations at Aljamarat Bridge [Al-Kodmany|2013).

4.28 Al-Kodmany (2013) used both Myriad 2 and Legion crowd models to test the new design of the Aljamarat Bridge. Legion is an ABM platform, focusing on modelling and simulating crowd behaviour, and ingress (entrance) and egress (exits) scenarios. In simulating evacuation scenarios, three situations were presented: choosing a random exit, choosing the nearest exit and all agents choosing the same exit. Agents can make movement decisions based on their current situations and constraints. A similar ABM platform, Myriad 2, was used for multiple purposes and at various scales. Its uniqueness relies on the integration of three different analytic techniques: network analysis; spatial analysis; and agent-based analysis. For instance, Myriad 2 can model a transport network for a large scale crowds, then simulate the crowd movements and behaviours within a complex environment, such as a railway station, and then experiments with many types of crowd reactions. The uniqueness of this model is in the integration of: Network analysis (to simulate crowd movements in large complex spaces); Spatial analysis model (analyse the utilised spaces in complex environments); and Agent analysis (for modelling systems with complex behaviours and experimenting with many types of options of crowd reactions).

4.29 Al-Kodmany 2013) applied specific parameters in the Myriad 2 simulations, such as entrance and exit width, building crowds around the pillars and crowd flows at the bridge. On the other hand, Legion was used to test the safety impacts. Results of combining Legion and Myriad 2 for Aljamarat Bridge indicated that the new bridge design, the capacity and the elliptical shapes of the new pillars would improve pilgrims' safety at the bridge. As an extension, Dridi (2014) joined Simulex with Myriad 2 to measure queue progression when approaching Aljamarat Bridge. Simulex is a micro simulation model for emergency egress combined with Myriad 2 to extract the information on pilgrim's crowd density, speed and arrival time at the bridge AlGadhi \& Still 2003). A Legion model was developed to improve the conceptual design of the Jamarat Bridge (Dridi|2014). Data on Aljamarat bridge capacity, viewing range of the three Jamarat pillars, in-flux and out-flux of the crowd, speed and resting times, ingress (entrance) capacity and increase in the exit capacity were used for validation. Moreover, the approved design of the new Jamarat Bridge, with five levels was further tested in other simulation models (Illyas 2013).

4.30 Illyas 2013 applied NetLogo, a widely known platform for ABM, to simulate activities at the Aljamarat Bridge. This platform allows users, both beginners and experienced, to design, programme, test and analyse scenarios, and develop a scientific understanding (Railsback et al. 2017). NetLogo is popular due to its professional design 
and packages, good visualization, comprehensive documentation, and high-level programming language with many built-in commands and data types specialised for ABMs. Furthermore, it has an integrated graphical user interface for performing simulation experiments (Kornhauser et al. 2009). For Aljamarat simulation, this model presented two types of agents: aggressive agents, who walk faster and move directly towards the Jamarat pillars without considering other pilgrims; and considerate agents, who walk slower and avoid crowds when moving towards the Jamarat. The simulation results match the real capacity of bridge $(125,000$ pilgrims per hour per level), and the rate of pilgrim flow on the bridge of 35 pilgrims $/ \mathrm{sec}$. A number of parameters were defined for this model. For example, the time required to perform this ritual, the stone throwing and the viewing range of the three Jamarat pillars. In addition, the analysis of pilgrims queueing and standing beside the Jamarat pillars was conducted for different shapes (circle and elliptical shapes). However, this study has not included many behaviours exhibited while performing the Ramy Jamarat ritual. These might include congestion effects (e.g. stampede), emotion or anxiety that may lead to irrational behaviours, or avoiding collisions and physical interaction. Nevertheless, this study could improve managing crowds at Aljamarat Bridge by examining each Jamarat level divided into zones, to identify the crowded areas at each level. This will help Hajj authorities to identify critical crowded zones on all Aljamarat Bridge levels, and to distribute pilgrims to other less crowded levels before any harm could happen.

4.31 Fayoumi et al. (2011) used STEPS, a crowd management microsimulation tool, to simulate pilgrim dynamics under normal and in emergency situations. The model was used to optimize crowd movement and assist in emergency egress management. In addition, their system was used to predict individuals' movements in 3Dspace. The authors ran four crowd simulation scenarios (models) A, B, C and D to improve the performance of pilgrim stoning processes in Hajj. Another main simulation result of this study was that the number of pilgrims performing Ramy ritual can be increased by $25 \%$ by increasing the Jamarat basin by $20 \%$. The results of this study could be used to develop the simulation of pilgrims on the Jamarat Bridge, expanding the architectural design of the Bridge and Jamarat pillars and assessing whether these expansions would affect the crowd management positively or negatively.

4.32 Klüpfel (2007) used a dynamic crowd model called PedGo, to simulate evacuation scenarios of large crowds of pilgrims (reaching 100,000 pilgrims at Aljamarat Bridge). This simulation showed how crowds separate during the process of evacuation, using the eight exits displayed in Figure 4.

4.33 Al-Kodmany 2013 highlighted that PedGo can run in real time. The outputs of this model include visual analysis, evacuation time, density plots and walking time. PedGo was used to test scenarios of crowd evacuation from Aljamarat Bridge. It simulated 100,000 pilgrims being evacuated from the bridge to the exits after $10 \mathrm{~min}$ utes of the emergency. Al-Kodmany (2013) mentioned that Klüpfel (2007) focused on the "potential" aspect of this simulation, as he assumed the pedestrians have a common sense of the task and all of them are aware of all the nearest exits from their locations and taking the shortest path. This study could also be used to simulate huge numbers of pilgrims in other places, such as Al-Masjid Al-Haram.
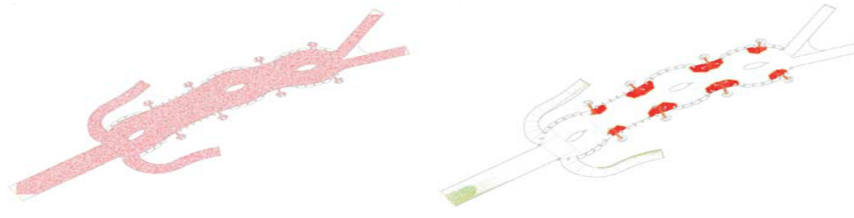

Figure 4: Simulating 100,000 agents to evacuate from Aljamarat Bridge. Sources: Klüpfel 2007.

4.34 PedGo is a crowd simulation model developed by Meyer-Konig and Klupfel (Sarmady et al. 2007) to simulate emergency evacuation of larger crowds. It was an outcome of a research project called BYPASS (Al-Kodmany 2013). PedGo can use different properties for the simulated pedestrians (e.g. maximum speed, patience, dawdle and sway) applying the normal probability distribution. In addition, as PedGo is a Cellular Automata (CA) model, it simulates the microscopic level of local movements of the pedestrians. Moreover, PedGo was applied to simulate emergency evacuation from crowded places (e.g. the egress from a sports stadium) (Klüpfel \& Meyer-König 2005. In their review, Kuligowski et al. 2005) compared PedGo model with other crowd models. They mentioned that the purpose of the model is to model and simulate crowd movement, and the evacuation of pedestrians from crowded places, such as buildings, ships, and other kinds of public transportation. PedGo uses as a network structure that divides the geometry of its floor plan into $0.4 \times 0.4 \mathrm{~m}$ grid cells and represents the space that is filled up by a person. In PedGo model, a set of rules is applied to all pedestrians regarding their movement in the model. However, PedGo is claimed to be a Multi-Agent model, but the description of the 
model does not correspond with the definition of autonomous agents (Kukla 2007) and the agents do not communicate with each other. This model is a stochastic model, which means that the behaviour of the modelled agent is determined by a parameterised probability distribution; each cell has a rule and transition occurs (e.g. if the next cell is empty, the agent can move into it) (Kukla 2007). PedGo is a microscopic CA model (Kukla 2007).

4.35 In conclusion, most of the simulation studies on Hajj have adopted and implemented ABM, CA and SFM, when modelling the Tawaf and Aljamarat rituals. ABM allows for heterogeneous agents to interact using simple rules and examining the emerging behaviour, while CA models can simplify crowd movements and representation, by using direct mapping of agent behaviours and cell update rules. However, CA (cells) do not present realistic behaviours and individual features. SFM provide continuous position representation of agents and use crowd movement foundation representing crowds as one homogeneous group (Sun 2013). These models can simulate normal crowd behaviours and evacuation situations, and some of them can simulate both conditions. Crowd modelling and simulation play a significant role in the development of new crowd management practices at mass gathering events.

\section{Discussions}

5.1 This paper presented a survey of crowd and pedestrian models used to test and examine crowd behaviours and movements for Hajj events. Previous studies on modelling and simulating pilgrims in Haram Mosque and Aljamarat Bridge have provided many insights on how to improve crowd management and have highlighted the limitations of both modelling and practices. Many studies used ABM and focused on studying pilgrims' behaviours at these sites, how pilgrims interact with each other (collision avoidance) and with the surroundings of these sites. Other studies used CA to model each individual movement while performing Tawaf and Sayee at Haram, and how pilgrims progress and choose empty spaces in their movement. Finally, other studies used SFM to analyse pilgrim flows, while they perform Tawaf ritual around the Ka'bah. Very few scholars (e.g. Sarmady et al. 2008) applied a combination of microscopic and macroscopic models, to study both pilgrim interactions with each other and their movements as a crowd at Tawaf ritual. Most of these Hajj studies focused on using types of Microscopic models (ABM, CA and SFM), which indicates that each pilgrim's behaviour and action can eventually affect the crowd movement at Haram and Aljamarat Bridge. Table 4 identifies the main gaps from the literature review:

- All studies used micro models, except Sarmady et al. 2008) used a combination of micro and macro;

- All studies only covered a simulation of two holy sites, presenting a fragmented view of the Hajj event;

- Most maximum number of agents simulated did not exceed 25,000, which is a small number compared to the real number of pilgrims at Hajj events.

Table 4: Analysis of previous studies.

\begin{tabular}{|c|c|c|c|c|c|}
\hline Authors & Study Description & $\begin{array}{l}\text { Model I } \\
\text { Type }\end{array}$ & Advantages/Benefits & $\begin{array}{l}\text { Crowd Man- } \\
\text { agement } \\
\text { Strategies }\end{array}$ & Gap \\
\hline \begin{tabular}{|l|} 
Al- \\
Kodmany \\
2013
\end{tabular} & $\begin{array}{l}\text { Myriad } \mathbf{2} \text { specifi- } \\
\text { cally developed by } \\
\text { Professor Still for } \\
\text { this purpose. The } \\
\text { software provided } \\
\text { detailed informa- } \\
\text { tion on Aljamarat } \\
\text { Bridge, such as arrival } \\
\text { capacity, throwing } \\
\text { area, space (as crowd } \\
\text { density was four } \\
\text { pilgrims/m }{ }^{2} \text { ) passing } \\
\text { areas and egress } \\
\text { capacity. }\end{array}$ & $\mathrm{ABM}$ & $\begin{array}{l}\text { Detailed information } \\
\text { about individuals } \\
\text { Natural matching } \\
\text { between agents and } \\
\text { individuals }\end{array}$ & $\begin{array}{l}\text { Provided assis- } \\
\text { tance for the } \\
\text { Hajj author- } \\
\text { ities for the } \\
\text { development of } \\
\text { pilgrims queu- } \\
\text { ing and entering } \\
\text { the Aljamarat } \\
\text { Bridge. }\end{array}$ & $\begin{array}{l}\text { These techniques } \\
\text { could be used to } \\
\text { improve Hajj crowd } \\
\text { management and ar- } \\
\text { chitectural designs at } \\
\text { other Hajj places (e.g. } \\
\text { Al-Masjid Al-Haram). }\end{array}$ \\
\hline
\end{tabular}

Continued on the next page 


\begin{tabular}{|c|c|c|c|c|c|}
\hline Authors & Study Description & $\begin{array}{l}\text { Model I } \\
\text { Type }\end{array}$ & Advantages/Benefits & $\begin{array}{l}\text { Crowd Man- } \\
\text { agement } \\
\text { Strategies }\end{array}$ & Gap \\
\hline$\frac{\mid \text { Dridi }}{2014}$ & $\begin{array}{l}\text { Applies the crowd } \\
\text { simulation model } \\
\text { PedFlow; verifica- } \\
\text { tion and validation } \\
\text { with video record- } \\
\text { ings of Hajj event } \\
2009 \text {. Comparisons } \\
\text { between PedFlow } \\
\text { and Simulex/Myriad } \\
\text { simulation models } \\
\text { results. }\end{array}$ & $A B M$ & $\begin{array}{l}\text { Pedflow is more } \\
\text { sophisticated in pre- } \\
\text { dicting the density } \\
\text { of crowd and its } \\
\text { dynamics. It can pro- } \\
\text { duce realistic crowd } \\
\text { motion with agent } \\
\text { moving at different } \\
\text { speeds and under } \\
\text { different situations } \\
\text { while using collisions } \\
\text { avoidance actions. }\end{array}$ & & $\begin{array}{l}\text { Using this simulator } \\
\text { with updated data } \\
\text { from crowds of pil- } \\
\text { grims performing } \\
\text { Tawaf and Sayee } \\
\text { rituals. Using this } \\
\text { simulator for other } \\
\text { Hajj crowd places } \\
\text { (e.g. Aljamarat } \\
\text { Bridge, Arafat and } \\
\text { Muzdalifah). }\end{array}$ \\
\hline \begin{tabular}{|l|} 
Fayoumi \\
et al. \\
2011
\end{tabular} & $\begin{array}{l}\text { STEPS, a microsimu- } \\
\text { lation tool, was used } \\
\text { for simulating pilgrim } \\
\text { dynamics under nor- } \\
\text { mal and emergency } \\
\text { situations. This tool } \\
\text { was additionally used } \\
\text { to predict individual' } \\
\text { movements in 3D } \\
\text { space. }\end{array}$ & $\mathrm{CA}$ & $\begin{array}{l}\text { Detailed information } \\
\text { about individuals' ac- } \\
\text { tions and behaviours. } \\
\text { Natural matching } \\
\text { between agents and } \\
\text { individuals }\end{array}$ & & $\begin{array}{l}\text { This technique could } \\
\text { be used to study } \\
\text { the relationships } \\
\text { between expanding } \\
\text { other Hajj places } \\
\text { and the crowd be- } \\
\text { haviours, movements } \\
\text { and flows. }\end{array}$ \\
\hline \begin{tabular}{|l|} 
Illyas \\
2013
\end{tabular} & $\begin{array}{l}\text { NetLogo ABM model } \\
\text { used for the ritual of } \\
\text { 'stoning the devil' at } \\
\text { the Aljamarat Bridge. } \\
\text { Used to simulate the } \\
\text { effect of different } \\
\text { parameters of pilgrim } \\
\text { movements, such } \\
\text { as space between } \\
\text { pilgrims and Jamarat } \\
\text { pillars, hitting range, } \\
\text { etc. }\end{array}$ & ABM & $\begin{array}{l}\text { Able to simulate two } \\
\text { types of individual be- } \\
\text { haviours. Able to sim- } \\
\text { ulate different shapes } \\
\text { of Aljamarat pillars. }\end{array}$ & $\begin{array}{l}\text { Analysing pil- } \\
\text { grims queuing } \\
\text { while standing } \\
\text { beside the three } \\
\text { Aljamarat pillars } \\
\text { for the throwing } \\
\text { ritual. }\end{array}$ & $\begin{array}{l}\text { This model could sim- } \\
\text { ulate agents at other } \\
\text { places, such as Tawaf } \\
\text { area. }\end{array}$ \\
\hline \begin{tabular}{|l|} 
Khan \& \\
McLeod \\
2012
\end{tabular} & $\begin{array}{l}\text { Investigated the } \\
\text { effect of Al-Masjid } \\
\text { Al-Haram courtyard } \\
\text { layout, pilgrim crowd } \\
\text { properties and crowd } \\
\text { management on } \\
\text { crowd safety a spread } \\
\text { of diseases via ABM. }\end{array}$ & ABM & $\begin{array}{l}\text { Provides guidance on } \\
\text { crowd management } \\
\text { for Tawaf area. }\end{array}$ & $\begin{array}{l}\text { Provided main } \\
\text { guidelines for } \\
\text { Tawaf crowd } \\
\text { management } \\
\text { (42 crowd } \\
\text { simulation } \\
\text { scenarios). }\end{array}$ & $\begin{array}{l}\text { The crowd manage- } \\
\text { ment results could be } \\
\text { applied on other Hajj } \\
\text { ritual sites. }\end{array}$ \\
\hline
\end{tabular}

Continued on the next page 


\begin{tabular}{|c|c|c|c|c|c|}
\hline Authors & Study Description & $\begin{array}{l}\text { Model I } \\
\text { Type }\end{array}$ & Advantages/Benefits & $\begin{array}{l}\text { Crowd Man- } \\
\text { agement } \\
\text { Strategies }\end{array}$ & Gap \\
\hline \begin{tabular}{|l|} 
Kim \\
et al. \\
2015
\end{tabular} & $\begin{array}{l}\text { Method to model } \\
\text { complex physical } \\
\text { interaction between } \\
\text { agents by using an } \\
\text { interactive velocity- } \\
\text { based multi-agent } \\
\text { FSM framework. } \\
35,000 \text { agents } \\
\text { were simulated in } \\
\text { dense scenarios (8 } \\
\text { agents/m²), while } \\
\text { interacting with other } \\
\text { agents and with } \\
\text { obstacles. }\end{array}$ & $A B M$ & $\begin{array}{l}\text { Combining velocity- } \\
\text { based and collection } \\
\text { avoidance algorithms } \\
\text { with physical forces } \\
\text { to model interactions } \\
\text { between agents and } \\
\text { obstacles in the sim- } \\
\text { ulated environment. } \\
\text { It allows agents to } \\
\text { anticipate and avoid } \\
\text { collisions during local } \\
\text { navigations (walking } \\
\text { in the environment). }\end{array}$ & - & $\begin{array}{l}\text { Improving modelling } \\
\text { by simulating pilgrim } \\
\text { behaviour (e.g. in- } \\
\text { teracting with other } \\
\text { agents, with the } \\
\text { environments' ob- } \\
\text { stacles and avoiding } \\
\text { collisions). }\end{array}$ \\
\hline \begin{tabular}{|l|} 
Klüpfel \\
2007
\end{tabular} & $\begin{array}{l}\text { PedGo applied to } \\
\text { simulate evacuation } \\
\text { scenarios of large } \\
\text { crowds (100,000 } \\
\text { pilgrims at Aljama- } \\
\text { rat Bridge). This } \\
\text { simulation showed } \\
\text { how crowds were } \\
\text { separated in the } \\
\text { evacuation process. }\end{array}$ & $\begin{array}{l}\mathrm{CA} / \text { multi- } \\
\text { agent }\end{array}$ & $\begin{array}{l}\text { Natural matching be- } \\
\text { tween agents and in- } \\
\text { dividuals. }\end{array}$ & $\begin{array}{l}\text { Analysing } \\
\text { emergency } \\
\text { situation (evac- } \\
\text { uation) of more } \\
\text { than 100,000 } \\
\text { pilgrims on Alja- } \\
\text { marat Bridge. }\end{array}$ & $\begin{array}{l}\text { This tool could be } \\
\text { used to simulate } \\
\text { evacuation scenarios } \\
\text { at other Hajj places. }\end{array}$ \\
\hline $\begin{array}{l}\text { Mahmood } \\
\text { et al. } \\
2017 \text {. }\end{array}$ & $\begin{array}{l}\text { Integrating Anylogic } \\
\text { model with external } \\
\text { modules for optimiza- } \\
\text { tion and analysis of } \\
\text { the crowd simulation, } \\
\text { to evaluate crowd } \\
\text { evacuation strategies. }\end{array}$ & $\mathrm{ABM}$ & $\begin{array}{l}\text { Model large crowds } \\
\text { in a spatial environ- } \\
\text { ment at real-scale, } \\
\text { simulation emer- } \\
\text { gency evacuation } \\
\text { under different ex- } \\
\text { perimental settings. } \\
\text { Complex behaviour, } \\
\text { such as emergency } \\
\text { evacuation, using } \\
\text { different experimen- } \\
\text { tal settings. Detailed } \\
\text { assessment of crowd } \\
\text { management and } \\
\text { control strategies. }\end{array}$ & $\begin{array}{l}\text { This frame- } \\
\text { work can be } \\
\text { implemented } \\
\text { for public safety } \\
\text { and security } \\
\text { management } \\
\text { during events } \\
\text { and other } \\
\text { supporting } \\
\text { decisions. }\end{array}$ & $\begin{array}{l}\text { The study did not } \\
\text { present any crowd } \\
\text { management strate- } \\
\text { gies in normal situa- } \\
\text { tions. The number of } \\
\text { the simulated agents } \\
\text { is small compared } \\
\text { to the real number } \\
\text { of pilgrims located } \\
\text { inside and outside } \\
\text { the Grand Mosque at } \\
\text { Hajj peak time. }\end{array}$ \\
\hline \begin{tabular}{|l|} 
Mulyana \\
$\& \quad$ Gu- \\
nawan \\
2010
\end{tabular} & $\begin{array}{l}\text { Simulated pilgrims } \\
\text { performing Tawaf as } \\
\text { "intelligent" agents. } \\
\text { Simulation matched } \\
\text { the practical per- } \\
\text { formance of real } \\
\text { pilgrims during Tawaf } \\
\text { and Sayee rituals. }\end{array}$ & $\mathrm{ABM}$ & $\begin{array}{l}\text { The simulation could } \\
\text { be used for training } \\
\text { purposes before } \\
\text { travelling to Al-Masjid } \\
\text { Al-Haram Kurdi et al. } \\
2015 \text {. }\end{array}$ & $\begin{array}{l}\text { Used as a pil- } \\
\text { grims training } \\
\text { tool for per- } \\
\text { forming Hajj } \\
\text { rituals. }\end{array}$ & $\begin{array}{l}\text { Increasing the num- } \\
\text { ber of informed } \\
\text { agents, to match } \\
\text { the real number of } \\
\text { pilgrims, could be } \\
\text { tested. Using sim- } \\
\text { ulation not only for } \\
\text { training, but also for } \\
\text { improving Hajj crowd } \\
\text { management. }\end{array}$ \\
\hline
\end{tabular}




\begin{tabular}{|c|c|c|c|c|c|}
\hline Authors & Study Description & $\begin{array}{l}\text { Model I } \\
\text { Type }\end{array}$ & Advantages/Benefits & $\begin{array}{l}\text { Crowd Man- } \\
\text { agement } \\
\text { Strategies }\end{array}$ & Gap \\
\hline \begin{tabular}{|l|} 
Nasir \& \\
Sunar \\
2016
\end{tabular} & $\begin{array}{l}\text { SFM and flocking } \\
\text { techniques applied } \\
\text { for simulation of } \\
\text { group behaviour in } \\
\text { a crowd in normal } \\
\text { situation while per- } \\
\text { forming the Tawaf } \\
\text { ritual }\end{array}$ & SFM & $\begin{array}{l}\text { Present several be- } \\
\text { haviours that were } \\
\text { observed from the } \\
\text { simulation of Tawaf. }\end{array}$ & $\begin{array}{l}\text { This model } \\
\text { helps to under- } \\
\text { stand pilgrim } \\
\text { behaviour in } \\
\text { a crowd and } \\
\text { assists Hajj } \\
\text { authorities to } \\
\text { plan for optimal } \\
\text { crowd flows } \\
\text { and prevent } \\
\text { incidents. }\end{array}$ & $\begin{array}{l}\text { Simulate group } \\
\text { behaviours under } \\
\text { emergency situations } \\
\text { such as evacuation. } \\
\text { Increase the number } \\
\text { of agents to the real } \\
\text { number of pilgrims } \\
\text { at Hajj. The flocking } \\
\text { technique could be } \\
\text { used for validating } \\
\text { simulating ABM sim- } \\
\text { ulation of individual } \\
\text { behaviour in a group. }\end{array}$ \\
\hline $\begin{array}{l}\text { Sarmady } \\
\text { et al. } \\
2008\end{array}$ & $\begin{array}{l}\text { Combined macro- } \\
\text { scopic model for } \\
\text { crowd movements } \\
\text { and CA, for collision } \\
\text { avoidance and use of } \\
\text { shorter paths during } \\
\text { Tawaf rituals. The in- } \\
\text { tegrated system was } \\
\text { capable of simulating } \\
\text { up to } 23,000 \text { agents } \\
\text { in real time. }\end{array}$ & $\begin{array}{l}\text { Hybrid } \\
\text { model } \\
\text { (Macro + } \\
\text { CA) }\end{array}$ & $\begin{array}{l}\text { The ability to simu- } \\
\text { late a large number } \\
\text { of crowds on a single } \\
\text { computer [42] }\end{array}$ & - & $\begin{array}{l}\text { Focus additionally } \\
\text { on simulating crowd } \\
\text { behaviours while } \\
\text { performing Tawaf } \\
\text { ritual (e.g. interacting } \\
\text { with other agents, } \\
\text { with obstacles and } \\
\text { avoiding collisions). }\end{array}$ \\
\hline \begin{tabular}{|l|} 
Siddiqui \\
$\&$ \\
Gwynne \\
2012
\end{tabular} & $\begin{array}{l}\text { Used EXODUS model } \\
\text { for simulating pil- } \\
\text { grims performing } \\
\text { the Sayee ritual at } \\
\text { the Grand Mosque } \\
\text { (Almasjid Alharam). }\end{array}$ & CA & $\begin{array}{l}\text { This model was used } \\
\text { to understand the im- } \\
\text { portance of individual } \\
\text { behaviour when sim- } \\
\text { ulating large crowds } \\
\text { of pilgrims (15,000 } \\
\text { agents). }\end{array}$ & $\begin{array}{l}\text { Provided prior } \\
\text { planning for } \\
\text { emergency sit- } \\
\text { uations for Hajj } \\
\text { events. }\end{array}$ & $\begin{array}{l}\text { This tool could be } \\
\text { used to simulate } \\
\text { evacuation scenar- } \\
\text { ios at other Hajj } \\
\text { places (e.g. Al-Masjid } \\
\text { Al-Haram). }\end{array}$ \\
\hline $\begin{array}{l}\text { Zainuddin } \\
\text { et al. } \\
2009\end{array}$ & $\begin{array}{l}\text { Simulated the cir- } \\
\text { cumambulation of } \\
\text { Ka'ba using SimWalk. } \\
\text { This study suggested } \\
\text { various mitigation } \\
\text { measures to ease } \\
\text { the pilgrims' flows in } \\
\text { the Tawaf area. The } \\
\text { results of this study } \\
\text { showed that building } \\
\text { the spiral path is an } \\
\text { effective solution in } \\
\text { ensuring a smooth } \\
\text { flow in Tawaf area. }\end{array}$ & SFM & $\begin{array}{l}\text { The ability to design } \\
\text { and analyse crowd } \\
\text { flows using SFM } \\
\text { Kurdi et al.2015 }\end{array}$ & $\begin{array}{l}\text { Proposed to } \\
\text { design new exits } \\
\text { for pilgrims } \\
\text { after complet- } \\
\text { ing their Tawaf } \\
\text { rituals (e.g., } \\
\text { building an } \\
\text { underground } \\
\text { tunnel or over- } \\
\text { head bridge to } \\
\text { exit from the } \\
\text { Grand Mosque } \\
\text { without in- } \\
\text { terfering with } \\
\text { the arriving } \\
\text { pilgrims). }\end{array}$ & $\begin{array}{l}\text { Increase the number } \\
\text { of simulated pilgrims } \\
\text { to match the real } \\
\text { number of pilgrims. }\end{array}$ \\
\hline
\end{tabular}

Continued from the previous page

\section{Conclusion}

6.1 Mass gathering (MG) events pose significant planning and management challenges. As a case study, Hajj is an 
MG event which attracts millions of pilgrims to perform rituals at four holy sites. This paper reviewed the latest crowd modelling and simulation studies, and the most important models and software packages used for the Hajj in both normal and emergency situations. Hajj is relevant as an MG event primarily because of its scale and one that faces major problems, such as overcrowding, congestion, people getting lost, stampedes, injuries and deaths. Therefore, Hajj authorities are interested in using models and latest technologies for planning the events and for managing pilgrims at the holy sites. Crowding problems can be studied prior to the events using simulation models. This paper identified three main groups of modelling techniques - agent-based modelling, cellular automata and social force - each with specific benefits and limitations. The paper critically assessed these models, identifying potential applications to other rituals or locations and directions for new research, which can assist the planning and operation of MG event, irrespective of their nature.

\section{Acknowledgements}

The main author of this paper is funded and sponsored by the Saudi Arabian Cultural Mission in Australia, the representative of the Royal Embassy of the Kingdom of Saudi Arabia.

The authors thank the reviewers and editors for their valuable comments which helped in improving the manuscript.

\section{Appendix: PRISMA 2009 Flow Diagram}

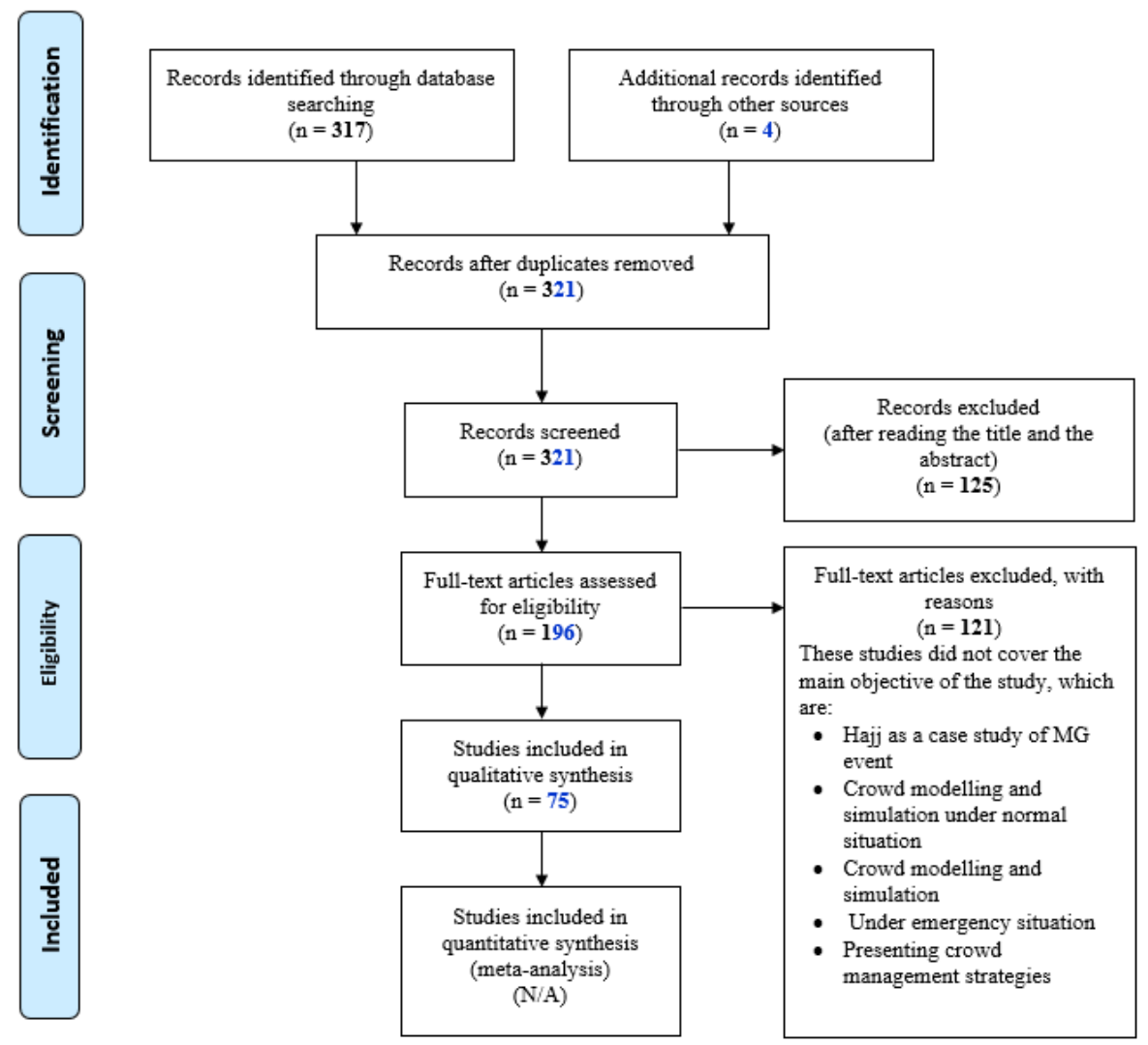

Figure 5: PRISMA flow diagram for the literature review. 
Table 5: Selection criteria for the literature review

\begin{tabular}{|c|c|c|c|c|c|c|}
\hline \multirow{2}{*}{$\begin{array}{l}\text { Study and year } \\
\text { of publication }\end{array}$} & \multirow{2}{*}{$\begin{array}{l}\text { Publication } \\
\text { Keywords }\end{array}$} & \multicolumn{5}{|c|}{ Selection Criteria } \\
\hline & & $\begin{array}{l}\text { Using Hajj } \\
\text { as a case } \\
\text { study of } \\
\text { MG event }\end{array}$ & $\begin{array}{l}\text { Describing } \\
\text { some de- } \\
\text { tail infor- } \\
\text { mation of } \\
\text { Hajj event }\end{array}$ & $\begin{array}{l}\text { Crowd } \\
\text { modelling } \\
\text { and simu- } \\
\text { lation for } \\
\text { normal } \\
\text { situation }\end{array}$ & $\begin{array}{l}\text { Crowd } \\
\text { modelling } \\
\text { and sim- } \\
\text { ulation } \\
\text { under } \\
\text { emer- } \\
\text { gency } \\
\text { situation }\end{array}$ & $\begin{array}{l}\text { Presenting } \\
\text { crowd } \\
\text { manage- } \\
\text { ment } \\
\text { proce- } \\
\text { dures and } \\
\text { strategies }\end{array}$ \\
\hline \begin{tabular}{|lll} 
Alaska & et & al. \\
2017 & & \\
\end{tabular} & $\begin{array}{l}\text { Mass gathering, } \\
\text { Jamarat, Hajj. }\end{array}$ & $\checkmark$ & $\checkmark$ & & & \\
\hline \begin{tabular}{|l|} 
Abdelghany \\
et al. 2016) \\
\end{tabular} & $\begin{array}{l}\text { Hajj, crowd dy- } \\
\text { namics, pedes- } \\
\text { trian flow. }\end{array}$ & $\checkmark$ & $\checkmark$ & & & \\
\hline \begin{tabular}{|l|} 
Abdelghany \\
et al. 2012$)$ \\
\end{tabular} & $\begin{array}{l}\text { Pedestrian } \\
\text { movements, } \\
\text { crowd manage- } \\
\text { ment, Makkah. }\end{array}$ & $\checkmark$ & $\checkmark$ & & & \\
\hline \begin{tabular}{|l} 
AlGadhi \& \\
2003
\end{tabular} & $\begin{array}{l}\text { Hajj, Aljama- } \\
\text { rat Bridge, } \\
\text { crowd mod- } \\
\text { elling, crowd } \\
\text { simulation. }\end{array}$ & $\checkmark$ & $\checkmark$ & $\checkmark$ & & \\
\hline \begin{tabular}{|l|l|} 
Aljohani 2015 \\
\end{tabular} & $\begin{array}{l}\text { Hajj, crowd } \\
\text { dynamics, Holy } \\
\text { Mosque, Holy } \\
\text { sites. }\end{array}$ & $\checkmark$ & $\checkmark$ & & & \\
\hline \begin{tabular}{|l|} 
Al-Kodmany \\
$2013)$
\end{tabular} & $\begin{array}{l}\text { Crowd manage- } \\
\text { ment, software } \\
\text { tools, design } \\
\text { testing, opera- } \\
\text { tional plans and } \\
\text { Hajj }\end{array}$ & $\checkmark$ & $\checkmark$ & $\checkmark$ & $\checkmark$ & $\checkmark$ \\
\hline \begin{tabular}{|l|} 
Al-Kodmany \\
(2011)
\end{tabular} & $\begin{array}{l}\text { Hajj, Aljamarat } \\
\text { Bridge, stoning } \\
\text { the devil, crowd } \\
\text { safety. }\end{array}$ & $\checkmark$ & $\checkmark$ & & & \\
\hline \begin{tabular}{|l|} 
Al-Nabulsi \\
2015
\end{tabular} & $\begin{array}{l}\text { Hajj, crowd, psy- } \\
\text { chology. }\end{array}$ & $\checkmark$ & $\checkmark$ & & & \\
\hline$\frac{\text { Al-Nabulsi }}{2009}$ & $\begin{array}{l}\text { Hajj, mass gath- } \\
\text { erings, risk as- } \\
\text { sessment. }\end{array}$ & $\checkmark$ & $\checkmark$ & & & \\
\hline $\begin{array}{l}\text { Alqahtani et al. } \\
\text { (2017) }\end{array}$ & $\begin{array}{l}\text { Hajj, mass } \\
\text { gathering, stam- } \\
\text { pede, crowd } \\
\text { disaster, crowd } \\
\text { incidents, Hajj } \\
\text { incidents }\end{array}$ & $\checkmark$ & $\checkmark$ & & & \\
\hline \begin{tabular}{|ll} 
Alshammari & $\&$ \\
Mikler $(2015)$ & \\
\end{tabular} & $\begin{array}{l}\text { Mass gather- } \\
\text { ings, Hajj. }\end{array}$ & $\checkmark$ & $\checkmark$ & & & \\
\hline $\begin{array}{l}\text { Amro \& Nijem } \\
2012)\end{array}$ & $\begin{array}{l}\text { Hajj, pilgrims, } \\
\text { tracking, lost. }\end{array}$ & $\checkmark$ & $\checkmark$ & & & \\
\hline
\end{tabular}

Continued on the next page 


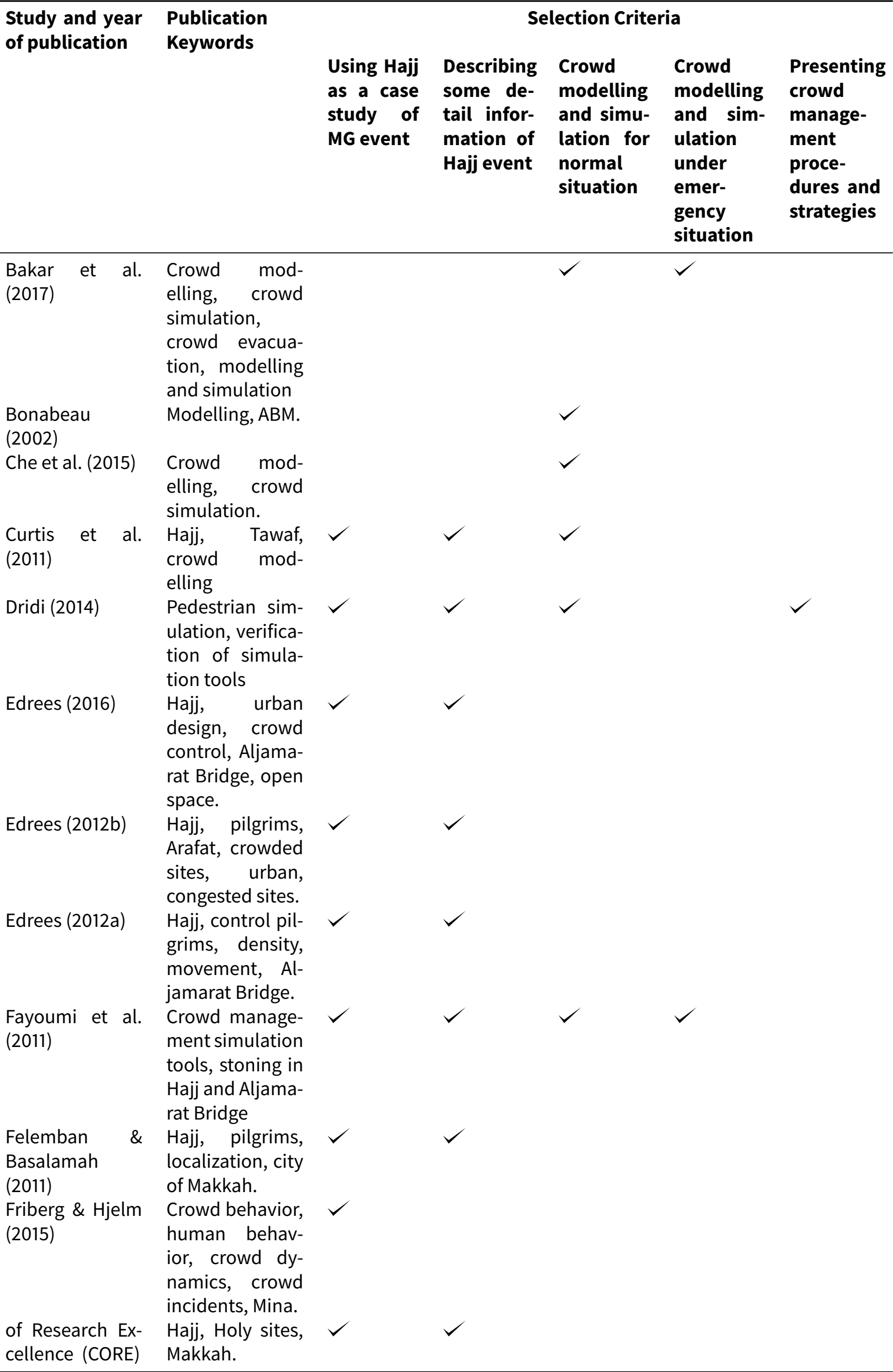

Continued on the next page 


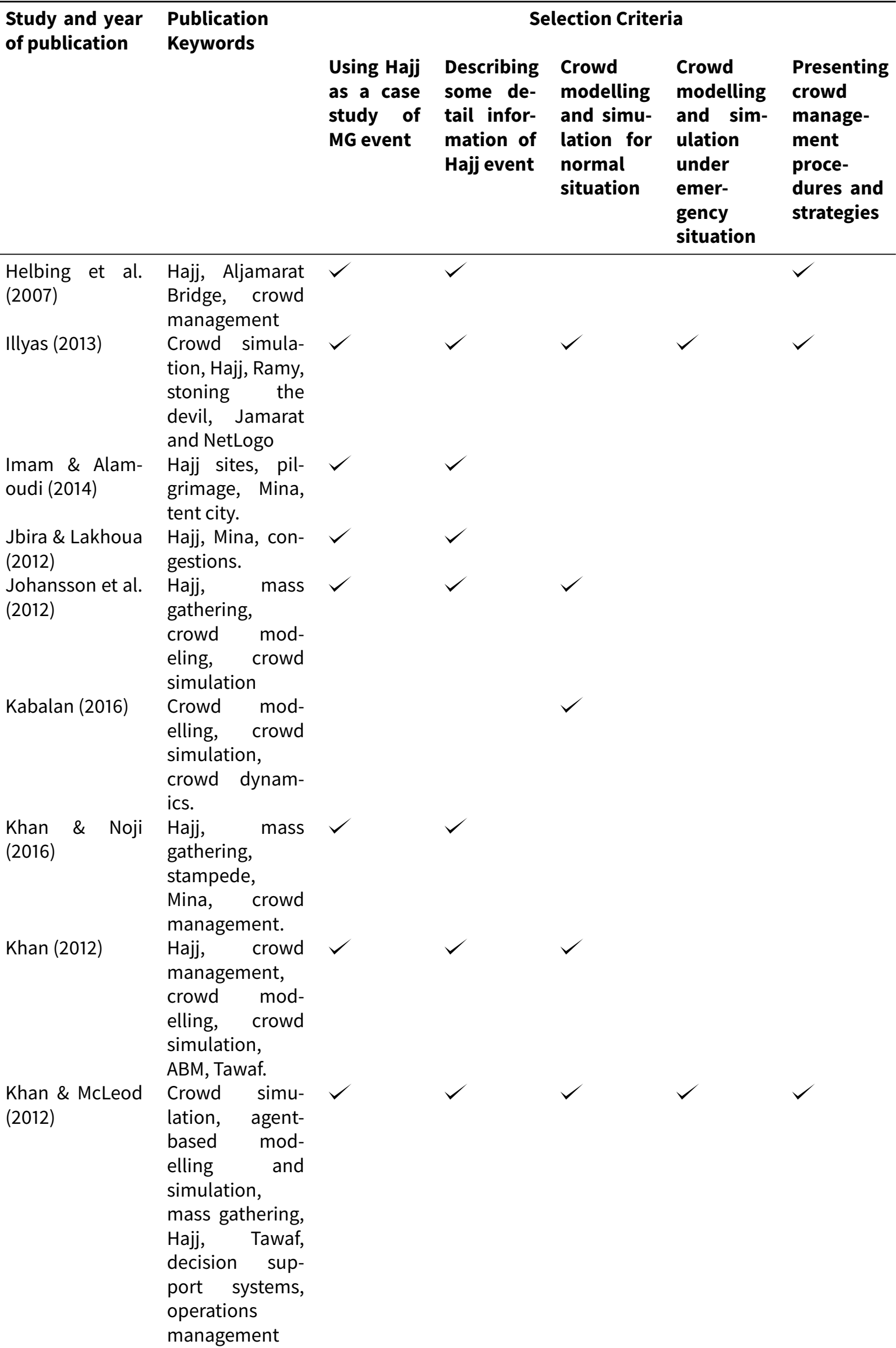

Continued on the next page 


\begin{tabular}{|c|c|c|c|c|c|c|}
\hline \multirow{2}{*}{$\begin{array}{l}\text { Study and year } \\
\text { of publication }\end{array}$} & \multirow{2}{*}{$\begin{array}{l}\text { Publication } \\
\text { Keywords }\end{array}$} & \multicolumn{5}{|c|}{ Selection Criteria } \\
\hline & & $\begin{array}{l}\text { Using Hajj } \\
\text { as a case } \\
\text { study of } \\
\text { MG event }\end{array}$ & $\begin{array}{l}\text { Describing } \\
\text { some de- } \\
\text { tail infor- } \\
\text { mation of } \\
\text { Hajj event }\end{array}$ & $\begin{array}{l}\text { Crowd } \\
\text { modelling } \\
\text { and simu- } \\
\text { lation for } \\
\text { normal } \\
\text { situation }\end{array}$ & $\begin{array}{l}\text { Crowd } \\
\text { modelling } \\
\text { and sim- } \\
\text { ulation } \\
\text { under } \\
\text { emer- } \\
\text { gency } \\
\text { situation }\end{array}$ & $\begin{array}{l}\text { Presenting } \\
\text { crowd } \\
\text { manage- } \\
\text { ment } \\
\text { proce- } \\
\text { dures and } \\
\text { strategies }\end{array}$ \\
\hline $\begin{array}{l}\text { Khozium et al. } \\
\text { 2012 }\end{array}$ & $\begin{array}{l}\text { Hajj, crowd } \\
\text { management, } \\
\text { crowd density, } \\
\text { crowd monitor- } \\
\text { ing, Nafrah. }\end{array}$ & $\checkmark$ & $\checkmark$ & & & \\
\hline Kim et al. (2015) & $\begin{array}{l}\text { Hajj, Tawaf } \\
\text { simulation, } \\
\text { Multi-agent sim- } \\
\text { ulation, Physical } \\
\text { interactions }\end{array}$ & $\checkmark$ & $\checkmark$ & $\checkmark$ & & $\checkmark$ \\
\hline Klüpfel (2007) & $\begin{array}{l}\text { Hajj, Al- } \\
\text { Jamaramt } \\
\text { Bridge, crowd } \\
\text { modelling, } \\
\text { crowd simula- } \\
\text { tion, pedestrian } \\
\text { flow, route } \\
\text { choice }\end{array}$ & $\checkmark$ & $\checkmark$ & $\checkmark$ & $\checkmark$ & $\checkmark$ \\
\hline \begin{tabular}{|l|} 
Klüpfel \& Meyer- \\
König (2005)
\end{tabular} & $\begin{array}{l}\text { Crowd mod- } \\
\text { elling and } \\
\text { simulation, } \\
\text { PedGo }\end{array}$ & & & & $\checkmark$ & \\
\hline \begin{tabular}{|l} 
Kornhauser \\
et al. (2009)
\end{tabular} & $\begin{array}{l}\text { Modelling, NetL- } \\
\text { ogo. }\end{array}$ & & & $\checkmark$ & & \\
\hline $\begin{array}{l}\text { Krausz \& Bauck- } \\
\text { hage (2011) }\end{array}$ & $\begin{array}{l}\text { Mass Gathering } \\
\text { events, crowd } \\
\text { management }\end{array}$ & & & & & $\checkmark$ \\
\hline Kukla 2007) & $\begin{array}{l}\text { Crowd mod- } \\
\text { elling and } \\
\text { simulations }\end{array}$ & & & $\checkmark$ & $\checkmark$ & \\
\hline $\begin{array}{l}\text { Kuligowski et al. } \\
2005)\end{array}$ & $\begin{array}{l}\text { Crowd mod- } \\
\text { elling and } \\
\text { simulation }\end{array}$ & & & $\checkmark$ & $\checkmark$ & \\
\hline Kurdi (2017) & $\begin{array}{l}\text { Crowd mod- } \\
\text { elling, crowd } \\
\text { simulation, } \\
\text { crowd behav- } \\
\text { iors, Hajj, Sayee. }\end{array}$ & $\checkmark$ & $\checkmark$ & $\checkmark$ & $\checkmark$ & \\
\hline$\frac{\text { Kurdi et al. }}{2015}$ & $\begin{array}{l}\text { Hajj, modelling, } \\
\text { simulation, } \\
\text { ABM, crowd } \\
\text { modelling, } \\
\text { crowd simu- } \\
\text { lation, Tawaf, } \\
\text { Sayee. }\end{array}$ & $\checkmark$ & $\checkmark$ & $\checkmark$ & $\checkmark$ & \\
\hline
\end{tabular}




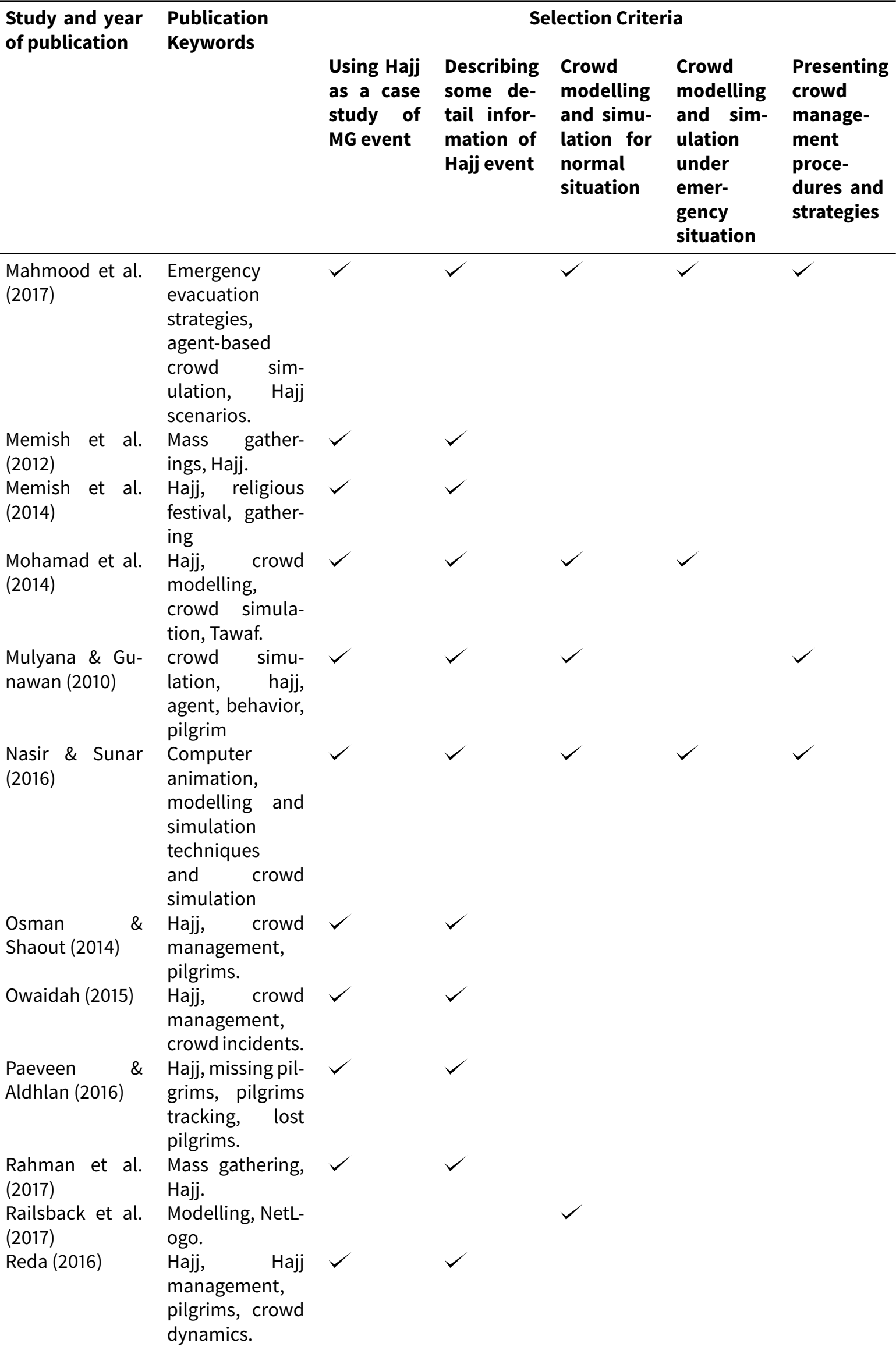

Continued on the next page 


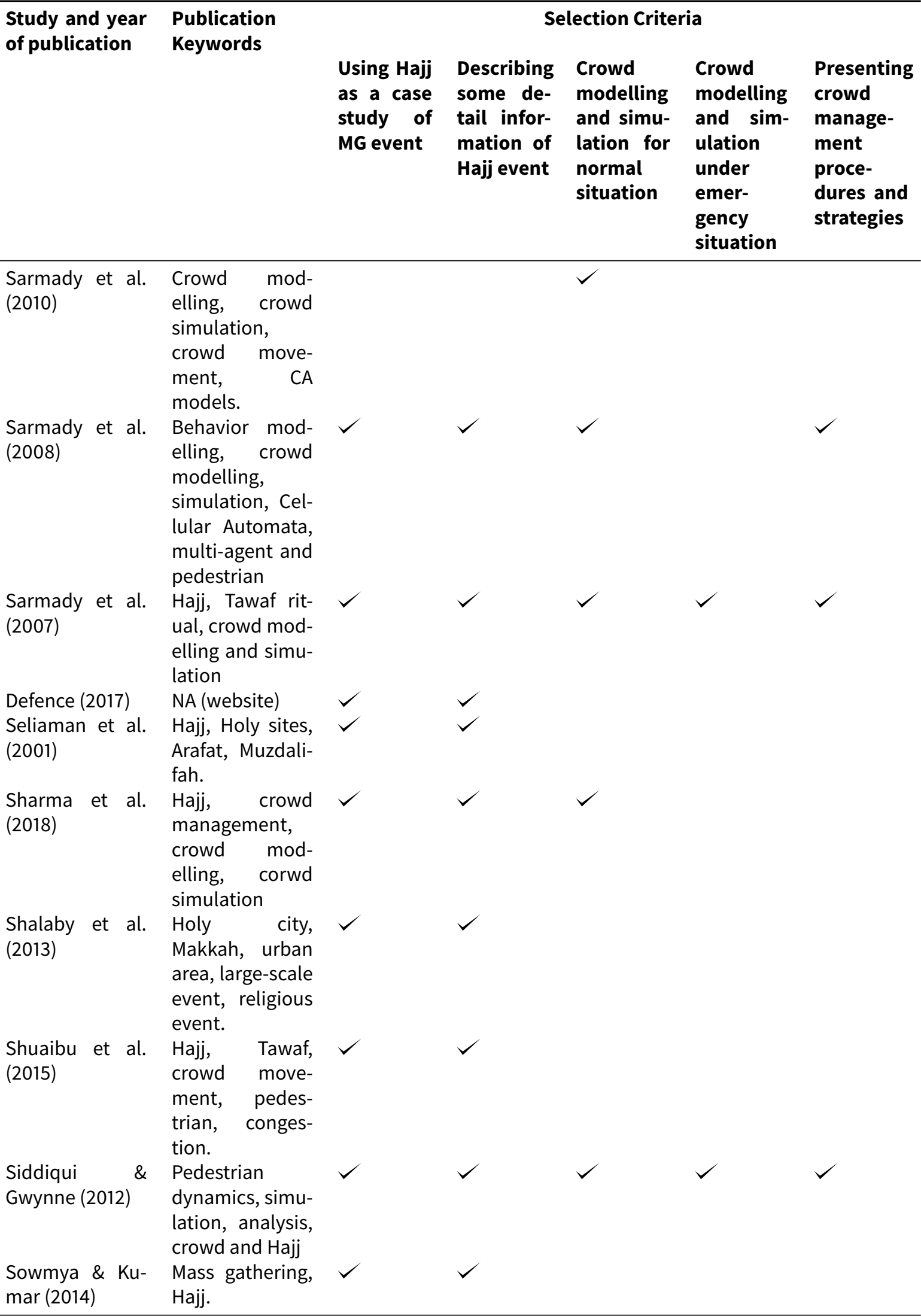

Continued on the next page 


\begin{tabular}{|c|c|c|c|c|c|c|}
\hline \multirow{2}{*}{$\begin{array}{l}\text { Study and year } \\
\text { of publication }\end{array}$} & \multirow{2}{*}{$\begin{array}{l}\text { Publication } \\
\text { Keywords }\end{array}$} & \multicolumn{5}{|c|}{ Selection Criteria } \\
\hline & & $\begin{array}{l}\text { Using Hajj } \\
\text { as a case } \\
\text { study of } \\
\text { MG event }\end{array}$ & $\begin{array}{l}\text { Describing } \\
\text { some de- } \\
\text { tail infor- } \\
\text { mation of } \\
\text { Hajj event }\end{array}$ & $\begin{array}{l}\text { Crowd } \\
\text { modelling } \\
\text { and simu- } \\
\text { lation for } \\
\text { normal } \\
\text { situation }\end{array}$ & $\begin{array}{l}\text { Crowd } \\
\text { modelling } \\
\text { and sim- } \\
\text { ulation } \\
\text { under } \\
\text { emer- } \\
\text { gency } \\
\text { situation }\end{array}$ & $\begin{array}{l}\text { Presenting } \\
\text { crowd } \\
\text { manage- } \\
\text { ment } \\
\text { proce- } \\
\text { dures and } \\
\text { strategies }\end{array}$ \\
\hline Sun 2013 & $\begin{array}{l}\text { Crowd mod- } \\
\text { elling, crowd } \\
\text { simulation, } \\
\text { crowd behav- } \\
\text { ior, individual } \\
\text { behavior. }\end{array}$ & & & $\checkmark$ & & \\
\hline H \& S. 2015 & $\begin{array}{l}\text { Crowd manage- } \\
\text { ment, Hajj }\end{array}$ & $\checkmark$ & $\checkmark$ & & & \\
\hline Tayan 2010 & Hajj, Holy sites. & $\checkmark$ & $\checkmark$ & & & \\
\hline Tunasar 2013 & $\begin{array}{l}\text { Hajj, pilgrims, } \\
\text { Mecca. }\end{array}$ & $\checkmark$ & $\checkmark$ & & & \\
\hline Turris et al. & $\begin{array}{l}\text { Mass Gathering } \\
\text { events }\end{array}$ & $\checkmark$ & & & & \\
\hline Office 2009 & $\begin{array}{l}\text { Crowd be- } \\
\text { havior, Hajj, } \\
\text { crowd mod- } \\
\text { elling, crowd } \\
\text { simulation. }\end{array}$ & $\checkmark$ & $\checkmark$ & $\checkmark$ & $\checkmark$ & $\checkmark$ \\
\hline Yamin 2015 & $\begin{array}{l}\text { Hajj, crowd } \\
\text { management, } \\
\text { crowd, pilgrims. }\end{array}$ & $\checkmark$ & $\checkmark$ & & & \\
\hline$\frac{\text { Yaseen et al. }}{2013}$ & $\begin{array}{l}\text { Hajj, pilgrimage, } \\
\text { Mecca, crowd } \\
\text { safety. }\end{array}$ & $\checkmark$ & $\checkmark$ & & & \\
\hline $\begin{array}{l}\text { Zainuddin et al. } \\
2009\end{array}$ & $\begin{array}{l}\text { Hajj, crowd } \\
\text { modelling, } \\
\text { crowd simu- } \\
\text { lation, Tawaf } \\
\text { simulation, } \\
\text { pedestrian flow, } \\
\text { Ka'aba, SFM. }\end{array}$ & $\checkmark$ & $\checkmark$ & $\checkmark$ & & $\checkmark$ \\
\hline$\frac{\text { Zawbaa \& Aly }}{2012)}$ & $\begin{array}{l}\text { Hajj, Umrah, } \\
\text { Hajj rituals. }\end{array}$ & $\checkmark$ & $\checkmark$ & & & \\
\hline
\end{tabular}




\begin{tabular}{|c|c|c|c|}
\hline Section/topic & $\#$ & Checklist item & Reported on page \# \\
\hline \multicolumn{4}{|l|}{ TITLE } \\
\hline Title & 1 & $\begin{array}{l}\text { Identify the report as a systematic review, meta- } \\
\text { analysis, or both. }\end{array}$ & Title of the paper \\
\hline \multicolumn{4}{|c|}{ (1) } \\
\hline Structured summary & 2.1 & $\begin{array}{l}\text { Provide a structured summary including, as applica- } \\
\text { ble: background; objectives; data sources; study eligi- } \\
\text { bility criteria, participants, and interventions; study ap- } \\
\text { praisal and synthesis methods; results; limitations; con- } \\
\text { clusions and implications of key findings; systematic re- } \\
\text { view registration number. }\end{array}$ & 2.1 \\
\hline \multicolumn{4}{|l|}{ INTRODUCTION } \\
\hline Rationale & 3 & $\begin{array}{l}\text { Describe the rationale for the review in the context of } \\
\text { what is already known. }\end{array}$ & 2.1 \\
\hline Objectives & 4 & $\begin{array}{l}\text { Provide an explicit statement of questions being ad- } \\
\text { dressed with reference to participants, interventions, } \\
\text { comparisons, outcomes, and study design (PICOS). }\end{array}$ & 2.1 \\
\hline \multicolumn{4}{|l|}{ METHODS } \\
\hline $\begin{array}{l}\text { Protocol and registra- } \\
\text { tion }\end{array}$ & 5 & $\begin{array}{l}\text { Indicate if a review protocol exists, if and where it can be } \\
\text { accessed (e.g., Web address), and, if available, provide } \\
\text { registration information including registration number. }\end{array}$ & $\mathrm{N} / \mathrm{A}$ \\
\hline Eligibility criteria & 6 & $\begin{array}{l}\text { Specify study characteristics (e.g., PICOS, length of } \\
\text { follow-up) and report characteristics (e.g., years consid- } \\
\text { ered, language, publication status) used as criteria for } \\
\text { eligibility, giving rationale. }\end{array}$ & $\begin{array}{l}\text { Table } 5 \text { Selection cri- } \\
\text { teria for the literature } \\
\text { review }\end{array}$ \\
\hline Information sources & 7 & $\begin{array}{l}\text { Describe all information sources (e.g., databases with } \\
\text { dates of coverage, contact with study authors to identify } \\
\text { additional studies) in the search and date last searched. }\end{array}$ & 2.1 \\
\hline Search & 8 & $\begin{array}{l}\text { Present full electronic search strategy for at least one } \\
\text { database, including any limits used, such that it could } \\
\text { be repeated. }\end{array}$ & 2.1 \\
\hline Study selection & 9 & $\begin{array}{l}\text { State the process for selecting studies (i.e., screening, } \\
\text { eligibility, included in systematic review, and, if appli- } \\
\text { cable, included in the meta-analysis). }\end{array}$ & 2.1 \\
\hline $\begin{array}{l}\text { Data collection pro- } \\
\text { cess }\end{array}$ & 10 & $\begin{array}{l}\text { Describe method of data extraction from reports (e.g., } \\
\text { piloted forms, independently, in duplicate) and any } \\
\text { processes for obtaining and confirming data from inves- } \\
\text { tigators. }\end{array}$ & $N / A$ \\
\hline Data items & 11 & $\begin{array}{l}\text { List and define all variables for which data were sought } \\
\text { (e.g., PICOS, funding sources) and any assumptions and } \\
\text { simplifications made. }\end{array}$ & $\mathrm{N} / \mathrm{A}$ \\
\hline $\begin{array}{l}\text { Risk of bias in individ- } \\
\text { ual studies }\end{array}$ & 12 & $\begin{array}{l}\text { Describe methods used for assessing risk of bias of in- } \\
\text { dividual studies (including specification of whether this } \\
\text { was done at the study or outcome level), and how this } \\
\text { information is to be used in any data synthesis. }\end{array}$ & $\mathrm{N} / \mathrm{A}$ \\
\hline Summary measures & 13 & $\begin{array}{l}\text { State the principal summary measures (e.g., risk ratio, } \\
\text { difference in means). }\end{array}$ & $N / A$ \\
\hline Synthesis of results & 14 & $\begin{array}{l}\text { Describe the methods of handling data and combining } \\
\text { results of studies, if done, including measures of consis- } \\
\text { tency (e.g., 12) for each meta-analysis. }\end{array}$ & $\begin{array}{l}\text { Table } 5 \text { Selection cri- } \\
\text { teria for the literature } \\
\text { review }\end{array}$ \\
\hline $\begin{array}{l}\text { Risk of bias across } \\
\text { studies }\end{array}$ & 15 & $\begin{array}{l}\text { Specify any assessment of risk of bias that may affect } \\
\text { the cumulative evidence (e.g., publication bias, selec- } \\
\text { tive reporting within studies). }\end{array}$ & $\mathrm{N} / \mathrm{A}$ \\
\hline
\end{tabular}

Continued on the next page 


\begin{tabular}{|c|c|c|c|}
\hline Section/topic & $\begin{array}{l}\# \quad \text { Check- } \\
\text { list item }\end{array}$ & Reported on page \# & \\
\hline Additional analyses & 16 & $\begin{array}{l}\text { Describe methods of additional analyses (e.g., sensitiv- } \\
\text { ity or subgroup analyses, meta-regression), if done, in- } \\
\text { dicating which were pre-specified. }\end{array}$ & $\mathrm{N} / \mathrm{A}$ \\
\hline \multicolumn{4}{|c|}{$x_{0}$} \\
\hline Study selection & 17 & $\begin{array}{l}\text { Give numbers of studies screened, assessed for eligibil- } \\
\text { ity, and included in the review, with reasons for exclu- } \\
\text { sions at each stage, ideally with a flow diagram. }\end{array}$ & $\begin{array}{l}\text { Figure } 5 \text { PRISMA flow } \\
\text { diagram for the litera- } \\
\text { ture review }\end{array}$ \\
\hline Study characteristics & 18 & $\begin{array}{l}\text { For each study, present characteristics for which data } \\
\text { were extracted (e.g., study size, PICOS, follow-up pe- } \\
\text { riod) and provide the citations. }\end{array}$ & 2.1 \\
\hline $\begin{array}{l}\text { Risk of bias within } \\
\text { studies }\end{array}$ & 19 & $\begin{array}{l}\text { Present data on risk of bias of each study and, if avail- } \\
\text { able, any outcome level assessment (see item 12). }\end{array}$ & $\mathrm{N} / \mathrm{A}$ \\
\hline $\begin{array}{l}\text { Results of individual } \\
\text { studies }\end{array}$ & 20 & $\begin{array}{l}\text { For all outcomes considered (benefits or harms), } \\
\text { present, for each study: (a) simple summary data } \\
\text { for each intervention group (b) effect estimates and } \\
\text { confidence intervals, ideally with a forest plot. }\end{array}$ & $\mathrm{N} / \mathrm{A}$ \\
\hline Synthesis of results & 21 & $\begin{array}{l}\text { Present results of each meta-analysis done, including } \\
\text { confidence intervals and measures of consistency. }\end{array}$ & $\mathrm{N} / \mathrm{A}$ \\
\hline $\begin{array}{l}\text { Risk of bias across } \\
\text { studies }\end{array}$ & 22 & $\begin{array}{l}\text { Present results of any assessment of risk of bias across } \\
\text { studies (see Item 15). }\end{array}$ & $\mathrm{N} / \mathrm{A}$ \\
\hline Additional analysis & 23 & $\begin{array}{l}\text { Give results of additional analyses, if done (e.g., sensi- } \\
\text { tivity or subgroup analyses, meta-regression [see Item } \\
\text { 16]). }\end{array}$ & $\mathrm{N} / \mathrm{A}$ \\
\hline Study characteristics & 18 & $\begin{array}{l}\text { For each study, present characteristics for which data } \\
\text { were extracted (e.g., study size, PICOS, follow-up pe- } \\
\text { riod) and provide the citations. }\end{array}$ & 2.1 \\
\hline \multicolumn{4}{|l|}{ DISCUSSION } \\
\hline Summary of evidence & 24 & $\begin{array}{l}\text { Summarize the main findings including the strength of } \\
\text { evidence for each main outcome; consider their rele- } \\
\text { vance to key groups (e.g., healthcare providers, users, } \\
\text { and policy makers). }\end{array}$ & 5.4 to 6.1 \\
\hline Limitations & 25 & $\begin{array}{l}\text { Discuss limitations at study and outcome level (e.g., risk } \\
\text { of bias), and at review-level (e.g., incomplete retrieval of } \\
\text { identified research, reporting bias). }\end{array}$ & 5.4 to 6.1 \\
\hline Conclusions & 26 & $\begin{array}{l}\text { Provide a general interpretation of the results in the } \\
\text { context of other evidence, and implications for future } \\
\text { research. }\end{array}$ & 6.1 \\
\hline \multicolumn{4}{|l|}{ FUNDING } \\
\hline Funding & 27 & $\begin{array}{l}\text { Describe sources of funding for the systematic review } \\
\text { and other support (e.g., supply of data); role of funders } \\
\text { for the systematic review. }\end{array}$ & 6.1 \\
\hline
\end{tabular}




\begin{tabular}{|c|c|c|}
\hline Event dimension & Category/Criterion & Examples \\
\hline \multirow[t]{3}{*}{ Demographics } & Event Type & $\begin{array}{l}\text { Races, sport events (e.g., cycling), religious pilgrimages, cul- } \\
\text { tural events, and music festivals }\end{array}$ \\
\hline & Geography & $\begin{array}{l}\text { Environment bounded or unbounded, shifting or fixed foot- } \\
\text { print, site (and egress, multi or single venue) }\end{array}$ \\
\hline & Temporality & $\begin{array}{l}\text { Duration (days, hours), time of year, time of day, season, re- } \\
\text { current annual event vs first-time event, peak time of atten- } \\
\text { dance }\end{array}$ \\
\hline \multirow[t]{2}{*}{ Dynamics } & Crowd Type & $\begin{array}{l}\text { Gender mix, age mix, families, disabilities, special popula- } \\
\text { tions }\end{array}$ \\
\hline & Crowd behavior & $\begin{array}{l}\text { Density, activity levels, queuing, movement, behaviour } \\
\text { Predispositions, motivations, crowd movement, and flow }\end{array}$ \\
\hline \multirow[t]{3}{*}{ Design } & Protective Factors & $\begin{array}{l}\text { Crowd resilience, health promotion, illness prevention, po- } \\
\text { lice/security onsite }\end{array}$ \\
\hline & Special Hazards & $\begin{array}{l}\text { Climate, weather conditions, road/rail traffic, obstacle } \\
\text { course, infectious disease exposure, alcohol and drug use, } \\
\text { mosh pits, fireworks }\end{array}$ \\
\hline & Onsite Health Services & First aid only, higher level of care \\
\hline
\end{tabular}

Table 7: Classification of MG events

\begin{tabular}{|c|c|c|}
\hline Holy site/ Incident type & $\begin{array}{l}\text { Past incidents at The Grand Mosque (Al-Masjid Al- } \\
\text { Haram) }\end{array}$ & Causes of deaths \\
\hline Major (death) & $\begin{array}{l}\text { September 2015, } 107 \text { deaths at Haram Alqahtani et al. } \\
2017 \text {. }\end{array}$ & Collapse of a crane \\
\hline Middle (injury) & $\begin{array}{l}\text { September 2015, } 200 \text { injuries at Haram, from the collapse } \\
\text { of Crane (Alqahtani et al. 2017) }\end{array}$ & \\
\hline \multicolumn{3}{|c|}{ 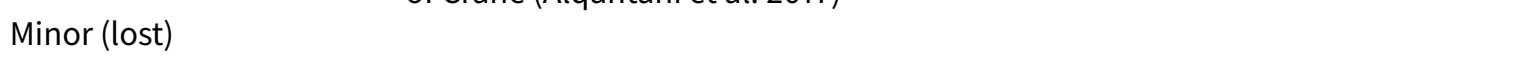 } \\
\hline & - 2006 - 2,500 lost at Haram (Paeveen \& Aldhlan|2016) & \\
\hline & $\begin{array}{l}\text { - } 2011 \text { - 3,000 lost at Haram and Hajj holy sites Amro } \\
\text { \& Nijem 2012, Paeveen \& Aldhlan 2016 }\end{array}$ & \\
\hline & - 2013 - 7,998 lost cases (Paeveen \& Aldhlan 2016 & \\
\hline
\end{tabular}

Table 8: Past incidents at the Grand Mosque (Al-Masjid Al-Haram)

Table 9: Past incidents at Mina city

\begin{tabular}{|c|c|c|}
\hline $\begin{array}{l}\text { Holy site/ Incident } \\
\text { type }\end{array}$ & $\begin{array}{l}\text { Past incidents at Mina City and Aljamarat } \\
\text { Bridge }\end{array}$ & Causes of deaths \\
\hline \multirow[t]{4}{*}{ Major (death) } & $\begin{array}{l}\text { September 2015, } 769 \text { deaths Khan \& Noji } \\
\text { 2016 Alqahtani et al. 2017 }\end{array}$ & \multirow{4}{*}{$\begin{array}{l}\text { Unknown reasons caused a stampede at } \\
\text { crossing of street } 204 \text { and } 223 \text { at tents city, } \\
\text { Mina (Khan \& Noji 2016; Alqahtani et al. 2017) } \\
\text { Some pilgrims were stumbled over and } \\
\text { caused stampede for arriving pilgrims at } \\
\text { the eastern access ramp Khan \& Noji 2016; } \\
\text { Alqahtani et al.|2017) } \\
\text { Unorganised pilgrims at the bridge carrying } \\
\text { their luggage and belongings.They caused } \\
\text { stampede for the crowd's movements on the } \\
\text { bridge (Alaska et al. 2017, Khan \& Noji 2016; } \\
\text { Alqahtani et al. 2017) }\end{array}$} \\
\hline & $\begin{array}{l}\text { January 2006, } 346 \text { deaths Khan \& Noji 2016, } \\
\text { Alqahtani et al. 2017) }\end{array}$ & \\
\hline & $\begin{array}{l}\text { February 2004, } 251 \text { deaths (Alaska et al.2017 } \\
\text { Khan \& Noji 2016; Alqahtani et al. 2017) }\end{array}$ & \\
\hline & & \\
\hline
\end{tabular}

Continued on the next page 


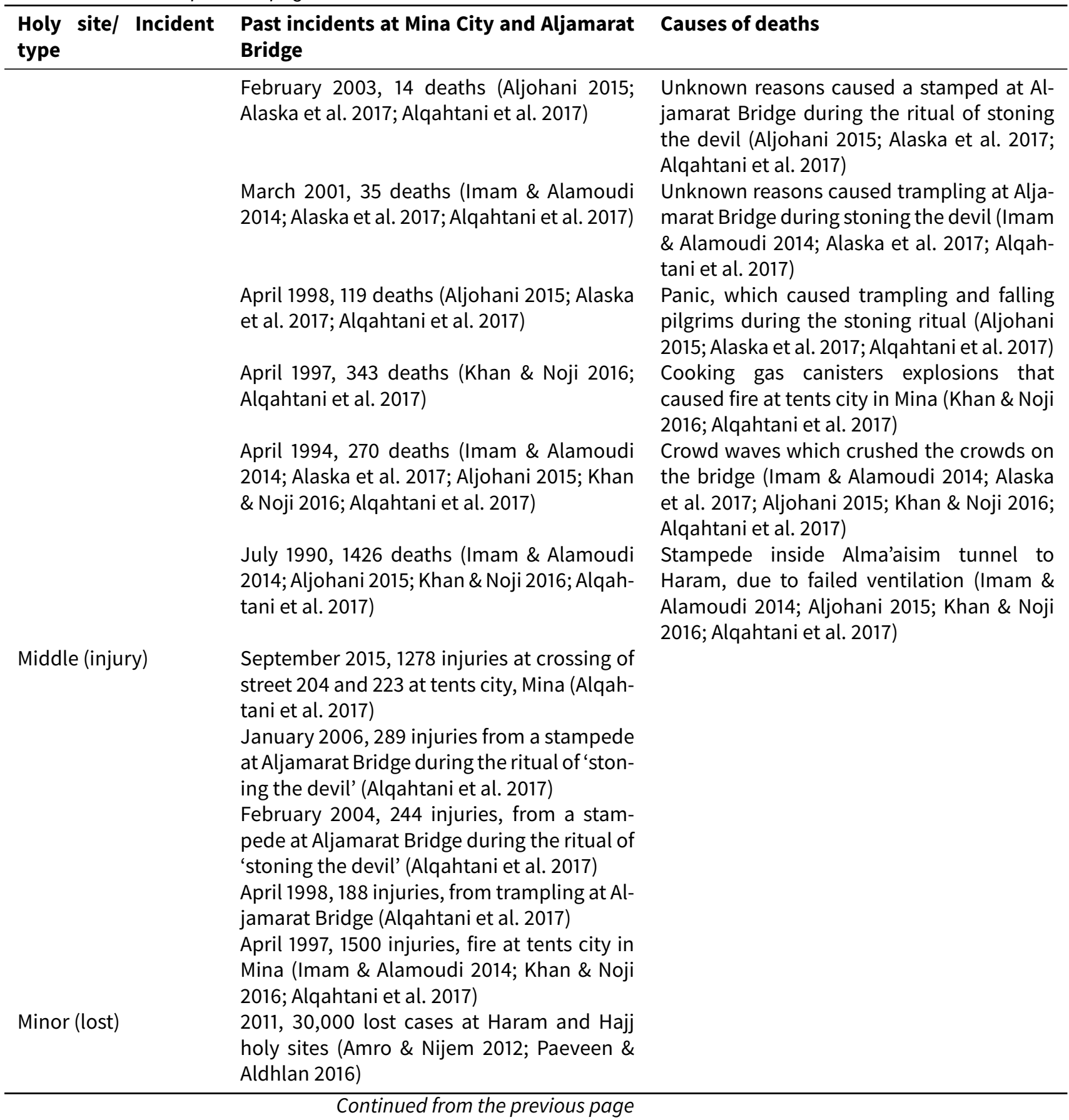

Continued from the previous page

\begin{tabular}{|c|c|c|}
\hline Holy site/ Incident type & $\begin{array}{l}\text { Arafat } \\
\text { Past }\end{array}$ & $\begin{array}{l}\text { Muzdalifah } \\
\text { Past }\end{array}$ \\
\hline Minor (lost) & $\begin{array}{l}\text { 2011, } 30.000 \text { lost at Haram and Hajj } \\
\text { holy sites (Amro \& Nijem 2012; Paeveen } \\
\text { \& Aldhlan 2016) }\end{array}$ & $\begin{array}{l}\text { 2011, 30,000 lost at Haram and Hajj } \\
\text { holy sites Amro \& Nijem 2012, Paeveen } \\
\text { \& Aldhlan 2016) }\end{array}$ \\
\hline
\end{tabular}

Table 10: Past incidents at Arafat and Muzdalifah 


\section{References}

Abdelghany, A., Abdelghany, K. \& Mahmassani, H. (2016). A hybrid simulation-assignment modeling framework for crowd dynamics in large-scale pedestrian facilities. Transportation Research Part A: Policy and Practice, $86,159-176$

Abdelghany, A., Abdelghany, K., Mahmassani, H. \& Al-Zahrani, A. (2012). Dynamic simulation assignment model for pedestrian movements in crowded networks. Transportation Research Record: Journal of the Transportation Research Board, 2316, 95-105

Al-Kodmany, K. (2011). Planning for safety: The case of the symbolic stoning of the devil in Hajj. Journal of Architectural and Planning Research, 28(1), 28-43

Al-Kodmany, K. (2013). Crowd management and urban design: New scientific approaches. Urban Design International, 18(4), 282-295

Al-Nabulsi, H. H. (2009). How Can Vulnerability and Risk Be Reduced in Large-Scale Gatherings? An Assessment of Vulnerability and Risk in Mass Gatherings. Master thesis, School of Built Environment, Oxford Brookes University, Oxford, UK

Al-Nabulsi, H. H. (2015). The Crowd Psychology of the Hajj. PhD Thesis, University of Sussex, UK

Alaska, Y. A., Aldawas, A. D., Aljerian, N. A., Memish, Z. A. \& Suner, S. (2017). The impact of crowd control measures on the occurrence of stampedes during mass gatherings: The Hajj experience. Travel Medicine and Infectious Disease, $15,67-70$

AlGadhi, S. A. \& Still, K. G. (2003). Jamarat bridge: Mathematical models, computer simulation and Hajjis safety analysis. Ministry of Hajj, Jeddah, Saudi Arabia

Aljohani, A. M. (2015). Pilgrim Crowd Dynamics. PhD thesis, University of Birmingham

Alqahtani, A. S., Yamazaki, K., Alqahtani, M., W H amd Tashani, Heywood, A. E., Booy, R., Wiley, K. E. \& Rashid, H. (2017). Australian Hajj pilgrims' perception about mass casualty incidents versus emerging infections at Hajj. Travel Medicine and Infectious Disease, 15, 81-83

Alshammari, S. M. \& Mikler, A. R. (2015). Modeling disease spread at global mass gatherings: Hajj as a case study. 2015 International Conference on Healthcare Informatics (ICHI). Dallas, TX

Amro, A. \& Nijem, Q. (2012). Pilgrims 'Hajj’ tracking system (e-Mutawwif). Contemporary Engineering Sciences, 5(9), 437-446

Bakar, N. A. A., Majid, M. A. \& Ismail, K. A. (2017). An overview of crowd evacuation simulation. Advanced Science Letters, 23(11), 11428-11431

Bonabeau, E. (2002). Agent-based modeling: Methods and techniques for simulating human systems. Proceedings of the National Academy of Sciences, 99(3S), 7280-7287

Cablová, L., Pates, R., Miovský, M. \& Noel, J. (2017). How to write a systematic review article and meta-analysis. In T. F. Babor, K. Stenius, R. Pates, M. Miovský, J. O’Reilly \& P. Candon (Eds.), Publishing Addiction Science: A Guide for the Perplexed, (pp. 173-189). London: Ubiquity Press

Che, X., Niu, Y., Shui, B., Fu, J., Fei, G., Goswami, P. \& Zhang, Y. (2015). A novel simulation framework based on information asymmetry to evaluate evacuation plan. The Visual Computer, 31(6-8), 853-861

Curtis, S., Guy, S. J., Zafar, B. \& Manocha, D. (2011). Virtual Tawaf: A case study in simulating the behavior of dense, heterogeneous crowds. 2011 IEEE International Conference on Computer Vision Workshops (ICCV Workshops). Barcelona, Spain

Defence, S. C. (2017). Saudi Civil Defence. http://www.998.gov.sa/AR/Pages/hajj.aspx, accessed 25/04/2017

Dridi, M. H. (2014). Pedestrian flow simulation validation and verification techniques. ArXiv preprint arXiv:1410.0603

Drury, J., Novelli, D. \& Stott, C. (2013). Representing crowd behaviour in emergency planning guidance: 'Mass panic' or collective resilience? Resilience, 1(1), 18-37 
Edrees, M. (2012a). Developing methods to control pilgrims' density and movement in Jamarat area. Available at https://www.researchgate.net/publication/310605027_Developing_Methods_ to_Control_Pilgrims_Density_and_Movement_in_Jamarat_Area

Edrees, M. (2012b). An urban study for crowded sites in Arafat area. Available at https ://www . researchgate. net/publication/309741711_An_Urban_Study_for_Crowded_Sites_in_Arafat_Area

Edrees, M. (2016). The role of urban design in crowd control: Case study 'Jamarat area'. Available at https://www.researchgate.net/publication/310346287_The_Role_of_Urban_Design_in_ Crowd_Control_Case_Study_Jamarat_Area

Fayoumi, A. G., Al-Ghoraibi, S., Fadel, A., Al-Aswadi, F. N., Mujallid, F. M. \& Wazzan, M. (2011). A simulator to improve the pilgrims' performance in stoning ritual in Hajj. International Journal of Computer Science and Network Security, 11(5), 141-144

Felemban, E. \& Basalamah, S. (2011). User requirements for localization and positioning during Hajj. International Conference on Indoor Positioning and Indoor Navigation (IPIN, 21-23 September 2011). Guimarães, Portugal

Friberg, M. \& Hjelm, M. (2015). Mass evacuation - Human behavior and crowd dynamics: What do we know? Department of Fire Safety Engineering. Lund University, Sweden

H, T. \& S., A. (2015). An examination of evolving crowd management strategies at pilgrimage sites: A case study of 'Hajj' in Saudi Arabia. International Journal of Mass Emergencies and Disasters, 33(2), 188-212

Halabi, W. S. (2006). Overcrowding and the Holy Mosque. Doctoral dissertation, University of Newcastle Upon Tyne

Helbing, D. \& Johansson, A. (2011). Pedestrian, crowd and evacuation dynamics. In R. Meyers (Ed.), Extreme Environmental Events, (pp. 697-716). New York, NY: Springer

Helbing, D., Johansson, A. \& Al-Abideen, H. Z. (2007). Dynamics of crowd disasters: An empirical study. Physical Review $E, 75,046109$

Illyas, Q. (2013). NetLogo model for Ramy Al-Jamarat in Hajj. Journal of Basic and Applied Scientific Research, 3(12), 199-209

Imam, A. \& Alamoudi, M. (2014). Mina: The city of tents origination and development. $9^{\circ}$ Congresso Città e Territorio Virtuale. Rome, 2-4 October 2013. UniversitÃă degli Studi Roma Tre

Jbira, M. K. \& Lakhoua, M. N. (2012). Functional analysis of congestion state caused by pilgrims crowd using SADT aiding on the design of a new supervisory system. Journal of Electrical and Electronics Engineering, 5(1), 105

Johansson, A., Batty, M., Hayashi, K., Al Bar, O., Marcozzi, D. \& Memish, Z. (2012). Crowd and environmental management during mass gatherings. The Lancet Infectious Diseases, 12(2), 150-156

Kabalan, B. (2016). Crowd Dynamics: Modelling Pedestrian Movement and Associated Generated Forces. PhD Thesis, Université Paris-Est

Khan, A. \& Noji, E. (2016). Hajj stampede disaster, 2015: Reflections from the frontlines. American Journal of Disaster Medicine, 11(1), 59-68

Khan, I. (2012). Hajj Crowd Management: Discovering Superior Performance with Agent-Based Modelling and Queueing Theory. PhD Thesis, University of Manitoba

Khan, I. \& McLeod, R. (2012). Managing Hajj crowd complexity: Superior throughput, satisfaction, health, \& safety. Kuwait Chapter of Arabian Journal of Business and Management Review, 2(4), 45-59

Khozium, M., Abuarafah, A. \& AbdRabou, E. (2012). A proposed computer-based system architecture for crowd management of pilgrims using thermography. Life Science Journal, 9(2), 377-383

Kim, S., Guy, J., Hillesland, K., Zafar, B., Gutub, A. \& Manocha, D. (2015). Velocity-based modelling of physical interactions in dense crowds. The Visual Computer, 31(5), 541-555 
Klüpfel, H. (2007). The simulation of crowd dynamics at very large events: Calibration, empirical data, and validation. In N. Waldau, P. Gattermann, H. Knoflacher \& M. Schreckenberg (Eds.), Pedestrian and evacuation dynamics 2005, (pp. 285-296). Berlin and Heidelberg: Springer

Klüpfel, H. \& Meyer-König, T. (2005). Simulation of the evacuation of a football stadium using the CA model PedGo. In S. P. Hoogendoorn, S. Luding, P. H. L. Bovy, M. Schreckenberg \& D. E. Wolf (Eds.), Traffic and Granular Flow '03, (pp. 423-428). Berlin and Heidelberg: Springer

Kornhauser, D., Wilensky, U. \& Rand, W. (2009). Design guidelines for agent based model visualization. Journal of Artificial Societies and Social Simulation, 12(2), 1

Krausz, B. \& Bauckhage, C. (2011). Automatic detection of dangerous motion behavior in human crowds. 2011 8th IEEE International Conference on Advanced Video and Signal Based Surveillance (AVSS). Klagenfurt, Austria

Kukla, R. (2007). A Software Framework for the Microscopic Modelling of Pedestrian Movement. Doctoral dissertation, Edinburgh Napier University

Kuligowski, E. D., Peacock, R. D. \& Hoskins, B. L. (2005). A review of building evacuation models. Gaithersburg, MD: US Department of Commerce, National Institute of Standards and Technology

Kurdi, O. (2017). Crowd Modelling and Simulation. PhD thesis, University of Sheffield

Kurdi, O., Stannett, M. \& Romano, D. (2015). Modelling and simulation of Tawaf and Sa'yee: A survey of recent work in the field. The European Simulation and Modelling Conference 2015, 26-28 Oct 2015, Leicester, UK

Mahmood, I., Haris, M. \& Sarjoughian, H. (2017). Analysing emergency evacuation strategies for mass gatherings using crowd simulation and analysis framework: Hajj scenario. In Proceedings of the 2017 ACM SIGSIM Conference on Principles of Advanced Discrete Simulation, (pp. 231-240). New York, NY: ACM

Memish, Z., Zumla, A., Alhakeem, R., Assiri, A., Turkestani, A., Al Harby, K. \& Alyemni, M. (2014). Hajj: Infectious disease surveillance and control. The Lancet, 383(9934), 2073-2082

Memish, Z. A., Stephens, G. M., Steffen, R. \& Ahmed, Q. A. (2012). Emergence of medicine for mass gatherings: Lessons from the Hajj. The Lancet Infectious Diseases, 12(1), 56-65

Mohamad, S., Sunar, M. \& Hanifa, R. (2014). A review on Tawaf crowd simulation: State-of-the-art. International Journal of Interactive Digital Media, 2(11), 119-123

Mulyana, W. \& Gunawan, T. (2010). Hajj crowd simulation based on intelligent agent. International Conference on Computer and Communication Engineering (ICCCE'10). Kuala Lumpur, Malaysia

Nasir, F. M. \& Sunar, M. S. (2016). Simulating large group behaviour in Tawaf crowd. 2016 Asia Pacific Conference on Multimedia and Broadcasting (APMediaCast). Bali, Indonesia

of Research Excellence (CORE), H. C. (2010). Background material toolkit. Umm Al Qura University. Available at: http://wwwusers.cs.umn.edu/ shekhar/talk/2013/Hajj\%20CORE\%20TOOLKIT_09042010.pdf

Office, U. C. (2009). Understanding crowd behaviours: Supporting evidence. Available at: https://www.gov.uk/government/uploads/system/uploads/attachment_data/file/192606/ understanding_crowd_behaviour-supporting-evidence.pdf

Osman, M. \& Shaout, A. (2014). Hajj guide systems: Past, present and future. International Journal of Emerging Technology and Advanced Engineering, 4(8), 25-31

Owaidah, A. (2015). Hajj Crowd Management Via a Mobile Augmented Reality Application: A Case of the Hajj Event, Saudi Arabia. Masters' Dissertation, University of Glasgow

Paeveen, Z. \& Aldhlan, K. (2016). Missing pilgrims tracking system using GPS, GSM and Arduino Microcontroller. International Conference on Recent Advances in Computer Systems (RACS 2015), 30 November - 1 December 2015, Hail, Saudi Arabia

Rahman, J., Thu, M., Arshad, N. \& Van der Putten, M. (2017). Mass gatherings and public health: Case studies from the Hajj to Mecca. Annals of Global Health, 83(2), 386-393

Railsback, S., Ayllón, D., Berger, U., Grimm, V., Lytinen, S., Sheppard, C. \& Thiele, J. (2017). Improving execution speed of models implemented in NetLogo. Journal of Artificial Societies and Social Simulation, 20(1), 3 
Reda, O. M. (2016). Mobile ad hoc networks group mobility models of Hajj crowd dynamics. International Journal of Applied Engineering Research, 11(22), 10772-10778

Reynolds, C. W. (1987). Flocks, herds, and schools: A distributed behavioral model. ACM SIGGRAPH Computer Graphics, 21(4), 25-34

Sarmady, S., Haron, F., Mohd Salahudin, M. M. \& Talib, A. Z. H. (2007). Evaluation of existing software for simulating of crowd at Masjid Al-Haram. Jurnal Pengurusan JAWHAR, 1(1), 83-95

Sarmady, S., Haron, F. \& Talib, A. Z. H. (2008). Multi-agent simulation of circular pedestrian movements using cellular automata. 2008 Second Asia International Conference on Modelling \& Simulation (AMS). Kuala Lumpur, Malaysia

Sarmady, S., Haron, F. \& Talib, A. Z. H. (2010). Simulating crowd movements using fine grid cellular automata. 2010 12th International Conference on Computer Modelling and Simulation (UKSim). Cambridge, United Kingdom

Seliaman, M., Duffuaa, S. \& Andijani, A. (2001). A stochastic simulation model for the design of a shuttle bus system to transport pilgrims in Hajj. Available at https://www.researchgate.net/publication/ 234060554_A_Stochastic_Simulation_Model_for_the_Design_of_a_Shuttle_Bus_System_to_ Transport_Pilgrims_in_Hajj

Shalaby, A., Isam, K., Al-Zahrani, A., Alshalalfah, B. \& Sayegh, A. (2013). Towards a sustainable transportation system for the Holy City of Makkah: Coping with harsh topography, dense urban area and large-scale religious events. 17th International Road Federation (IRF) World Meeting and Exhibition 2013, 10-14 November 2013. Riyadh, Saudi Arabia

Sharma, D., Bhondekar, A., Shukla, A. \& Ghanshyam, C. (2018). A review on technological advancements in crowd management. Journal of Ambient Intelligence and Humanized Computing, 9(3), 485âĂŞ-495

Shiwakoti, N. \& Sarvi, M. (2013). Understanding pedestrian crowd panic: A review on model organisms approach. Journal of Transport Geography, 26, 12-17

Shuaibu, A. N., Faye, I., Malik, A. \& Simsim, M. (2015). Simulation of crowd movement in spiral pattern during Tawaf, in Makkah, Saudi Arabia. Modern Applied Science, 9(11), 192-202

Siddiqui, A. A. \& Gwynne, S. M. V. (2012). Employing pedestrian observations in engineering analysis. Safety Science, 50(3), 478-493

Sowmya, M. \& Kumar, B. (2014). Smart way of tracking and assistance of pilgrims using android. International Journal of Engineering Trends and Technology (IJETT), 16(9), 410-413

Sun, Q. (2013). A Generic Approach to Modelling Individual Behaviours in Crowd Simulation. PhD Thesis, University of Salford, UK

Tayan, O. (2010). A proposed model for optimizing the flow of pilgrims between Holy sites during Hajj using traffic congestion control. Proceedings of the International Journal of Engineering and Technology, 10(2), 5559

Tunasar, C. (2013). Analytics driven master planning for Mecca: Increasing the capacity while maintaining the spiritual context of HAJJ pilgrimage. 2013 Winter Simulations Conference (WSC), 8-11 Dec 2013, Washington, DC

Turris, S. A., Lund, A., Hutton, A., Bowles, R., Ellerson, E., Steenkamp, M., Ranse, J. \& Arbon, P. (2014). Massgathering health research foundational theory: Part 2 - Event modeling for mass gatherings. Prehospital and Disaster Medicine, 29(6), 655âĂŞ-663

Ulicny, B. \& Thalmann, D. (2001). Crowd simulation for interactive virtual environments and VR training systems. In N. Magnenat-Thalmann \& D. Thalmann (Eds.), Computer Animation and Simulation 2001: Proceedings of the Eurographics Workshop in Manchester, UK, September 2-3, 2001, (pp. 163-170). Wien: Springer

Yamin, M. (2015). Secure and healthy Hajj management: A technological overview. American Academic \& Scholarly Research Journal, 7(3), 195-202 
Yaseen, S., Al-Habaibeh, A., Su, D. \& Otham, F. (2013). Real-time crowd density mapping using a novel sensory fusion model of infrared and visual systems. Safety Science, 57, 313-325

Zainuddin, Z., Thinakaran, K. \& Abu-Sulyman, I. M. (2009). Simulating the circumambulation of the Ka'aba using SimWalk. European Journal of Scientific Research, 38(3), 454-464

Zawbaa, H. \& Aly, S. A. (2012). Hajj and Umrah event recognition datasets. ArXiv preprint arXiv: 1205.2345 